\title{
The Effect of Employee Engagement on Organizational Performance Via the Mediating Role of Job Satisfaction: The Case of IT Employees in Jordanian Banking Sector
}

\author{
Mahmoud Al-dalahmeh ${ }^{1}$, Ra'ed Masa'deh ${ }^{1}$, Rana Khaled Abu Khalaf ${ }^{2} \&$ Bader Yousef Obeidat $^{2}$ \\ ${ }^{1}$ Management Information System Department, Jordan \\ ${ }^{2}$ Business Management Department, School of Business, the University of Jordan, Amman, Jordan \\ Correspondence: Mahmoud Al-dalahmeh, Management Information System Department, School of Business, The \\ University of Jordan, Amman, Jordan, Amman 11942, Jordan. Tel: 962-6535-5000. E-mail: \\ m.aldalahmeh@ju.edu.jo
}

Received: October 27, 2017

Accepted: March 13, 2018

Online Published: May, 10, 2018

doi:10.5539/mas.v12n6p17

URL: https://doi.org/10.5539/mas.v12n6p17

\begin{abstract}
This study sought to investigate the effect of IT employees' engagement on organizational performance through the mediating role of job satisfaction for IT employees within the IT Departments in Jordanian banking sector. Quantitative research design and regression analysis were applied on a total of 429 valid returns that were obtained in a questionnaire based survey. The results showed that IT employee engagement significantly affected organizational performance and three of its dimensions, vigor, absorption, and dedication contributed significantly to organizational performance. The results also showed that IT employee engagement positively and significantly affected job satisfaction, where vigor had the most contribution. In addition, it was found that job satisfaction significantly and positively affected organizational performance. Furthermore, job satisfaction only partially mediated the association between IT employee engagement and organizational performance. This study implies that IT departments in Jordanian banking should try their best to promote and facilitate IT employees' engagement and satisfaction in an effort to improve their performance, which will eventually yield positive results for the bank as a whole. In light of these results, the research presented many recommendations for future research, the most important ones were the application of this study in other sectors, cultures, and countries, the exploration of the moderating role of job satisfaction instead of mediating role, and the use of other sampling techniques.
\end{abstract}

Keywords: employee engagement, job satisfaction, organizational performance, IT employees, banking sector, Jordan

\section{Introduction}

Many companies realized that employees are organizations best assets that they can compete with internal and external organizations in their sectors (Bailey et al., 2016). In today's business world, employees' requirements go beyond the basic salary, which has shifted the focus of employers to understand the true essence of the employee engagement practices. Employees, in the present context, expect to be engaged in the organizational working, that is, their role should contribute and affect the business in a greater sense (Marciano, 2010). Employee engagement and employee-organizational commitments are critical organizational requirements as organizations face globalization, competitors and innovative individuals and others, specially recovering from the global recession to gain competitive advantage over the others (Bailey et al., 2016; Anitha, 2014).

Employee engagement and job satisfaction are regarded as interchangeable concepts; however; it is not necessary that a happy employee is always a healthy employee (Musgrove et al., 2014). Many researchers in their studies support the relationship between organizational performance and employees' engagement, for example, Albdour and Altarawneh (2014). It is very important for decision makers and diagnostic and practical researchers to rely on an evidence base to make tangible progress in the employee engagement practice, job satisfaction and company performance.

In this regard, this paper will cover the analysis of the effect of employee engagement on the organizational performance through the mediating role of job satisfaction for the IT employees. 
This paper is organized as follows: Section 2, sets the context of the need to study the associations among employee engagement, job satisfaction, and role of both these aspects of organizational performance. Section 3, specify the research conceptual framework and hypotheses. Section 4, indicates the research methodology. Section 5, show the research results and discussion. Section 6 concludes by presenting the implications and suggestions for future research.

\section{Literature Review}

Employee engagement is defined as a property of the relation between the organizations with their employees. In other words, employee engagement refers to the intellectual as well as the emotional commitment to an organization by their employees in their jobs (Amhalhal et. al, 2015). Moreover, employee engagement is a narrowintensive conceptualization of the relationship between the employee and his/her job (Yalabik et al., 2017). The employee engagement concept is about how to satisfy, and how happy are the employees with their jobs as well as the environment in which the employees work in with their colleagues.

In addition to this, employee engagement is, about how their work performance is associated or aligned with the outcomes of organization (Amhalhal et. al, 2015). Job satisfaction relates to perceived job quality, which stems from the individual consideration of all the monetary and non-monetary aspects of the job (Di Paolo, 2016). Thus, it is commonly seen as an individual's emotional response to perceived fulfilment of one's important job values. If these values are fulfilled, then the pleasurable emotion of satisfaction is experienced, if they are neglected, then the emotion of dissatisfaction is experienced (Bednarska and Szczyt, 2015). Unsatisfied employees show deviant workplace behavior and exit planning, which in turn decrease service quality and job performance (Tuna et al., 2016).Moreover employee job satisfaction has long been considered as one of the key determinants of an organization's success and growth (Prajogo and Cooper, 2017).

Considerable interest in employee engagement emerged; nonetheless clear indications of cause and effect were unclear in much of these studies. Furthermore, few studies have shown clear links between initiatives undertaken by managers and organizations that improve employee engagement and performance. Every organization that exists has different characteristics and conditions whichmake it difficult to have initiatives that can be readily adopted by organizations (Bandura and Lyons, 2014).

In addition, engaged employees are likely to have trusting and high quality relationships with their employer (Saks, 2006; Karatepe, 2011). These engaged employees in turn perform their tasks more effectively and go the extra mile in dealing with customer problems and attending to the needs of customers. Although a number of studies, including this study, agree that engagement affects performance, few studies beg to differ. For instance, Halbesleben and Wheeler (2008) conducted a study on a sample of 587 employees in the United States from a variety of industries and found that work engagement has a small effect on performance. In addition, research by Gallup organization revealed a low to moderate correlation between employee engagement and a range of organizational outcomes such as customer satisfaction, profit, productivity, turnover, and safety (Harter et al., 2002).

In spite of vigor having the most influence on job satisfaction as found in this study, previous studies have revealed that that dedication influences job satisfaction more than vigor and absorption (Alarcon and Edwards, 2011). Dedication is characterized by a strong sense of significance, enthusiasm, inspiration, pride, purpose and challenge toward accomplishing goals (Karatepe and Olugbade, 2009; Schaufeli et al., 2009). It resembles involvement and is defined as a psychological identification one has with his/her job (Schaufeli et al., 2009). In other words, this dimension captures one's cognitive belief and affective interaction with his/her works. Moreover, dedication represents an interactive mode where employees gain challenge, inspiration, pride and the sense of meaning by engaging themselves within their work. This interactive mode of work engagement, thus, contributes to employees' job satisfaction and suppresses intentions to quit.

\subsection{Research Significant}

The main contribution of this paper is the way of measuring organizational performance that will be comprehensive using financial and nonfinancial performance as discussed in the literature review, while examining the mediating role of job satisfaction. The major importance of this paper is that it is one of few researches to figure out the mediating role of job satisfaction and it will be helpful in analyzing the significance of the engagement of IT employees in the banking sector. The paper is particularly significant in examining the effect of IT employees' engagement on their satisfaction levels. In addition to this, the paper is important or significant in terms of examining the role as well as the impact of IT employee engagement and job satisfaction on the performance of organizations. In this sense, the paper will be helpful in attaining the knowledge regarding the importance of engagement of IT employees for the potential success of the organization. Moreover, this paper will be helpful for 
other researchers in conducting further researches in the future on the same or related topics. Indeed,

\subsection{Gap in The Research}

- Moreover, job satisfaction has been found to lead to positive workplace attitudes, intentions, behaviours, and performance outcomes both directly and indirectly at different levels (Bednarska and Szczyt, 2015). Literature has revealed that satisfaction at work is a strong determinant of organizational identification and commitment (Efraty and Sirgy, 1990; Chen, 2007; Back et al., 2011), withdrawal or counterproductive behaviours (Firth et al., 2004; Mount et al., 2006), in-role and extra-role behaviours (Efraty and Sirgy, 1990; Lee et al., 2006), service quality (Yoon and Suh, 2003), and organizational performance (Hwang and Chi, 2005; Yee et al., 2011).

- As a result, job satisfaction can be considered as a mediating variable in this paper given its association with different work related behaviours. Given the need to explore the effect of employee engagement on organizational performance, and how employee engagement affects performance, this research is conducted with the focus of studying the effect of employee engagement on organizational performance through the mediating role of job satisfaction in the IT employees within Jordanian banking sector in an effort to enrich existent literature.

- Based on the Information Systems Strategy Triangle, a company has to balance its commerce, organizational and information systems strategies to be booming. It is, consequently, not amazing that the job satisfaction of the IT employees is leading to the achievement of any commerce these existences.

- Few empirical studies exist regarding the job satisfaction of banking Information Technology (IT) employees, despite the growth of IT employees in banking sector.

- Firms are driven to follow business value by continuously investing heavily in sophisticated IT solutions such as Web services, data warehousing, enterprise application interfaces, and extended enterprise networks (Sambamurthy et al., 2003). Users in functional units must cooperate carefully with their IT departments to continuously integrate their emerging business needs into these IT solutions in order to create and sustain competitive advantages (Sambamurthy et al. 2003). In this framework, the relationship between users in the functional unit and those in the IT unit becomes critical to achieving joint collaboration success.

- Shortage of literature in developing countries to find the effect of job satisfaction in IT employees' engagement and the company performance.

- The increment in the IT field in Jordan.

- This paper is one of the first to develop and empirically test a new model of the mediating role of IT employees job satisfaction on organization performance. Moreover, the paper outlines relevant research avenues for researchers investigating related literature.

\section{Research Framework and Hypotheses}

This research was conducted to demonstrate the effect of employee engagement on organizational performance through the mediating role of job satisfaction in the Jordanian banking sector, where this sector is highly important and competitive.

\subsection{Operational Definitions}

The following section elaborates operational definitions for the study variables and their dimensions based on previous studies of employee engagement, organizational performance and job satisfaction. All items were measured using a five-point rating scale rating from one: 'strongly disagree' to five: 'strongly agree'.

\subsubsection{Employee Engagement (Independent Variable)}

Employee engagement was operationalized using the dimensions of vigor, dedication, and absorption. Each of the three dimensions was measured using the items provided in table (1), where vigor included 6 items derived from the study conducted by (Ariani, 2013; Schaufeli et al., 2006), dedication included 5 items derived from the study conducted by (Ariani, 2013; Ferreira and de Oliveira, 2014), and absorption included 5 items derived from the study conducted by (Ariani, 2013; Schaufeli et al, 2006).

Table (1). Employee Engagement Measurements

\begin{tabular}{l} 
Employee Engagement \\
\hline Vigor (Dimension)
\end{tabular}




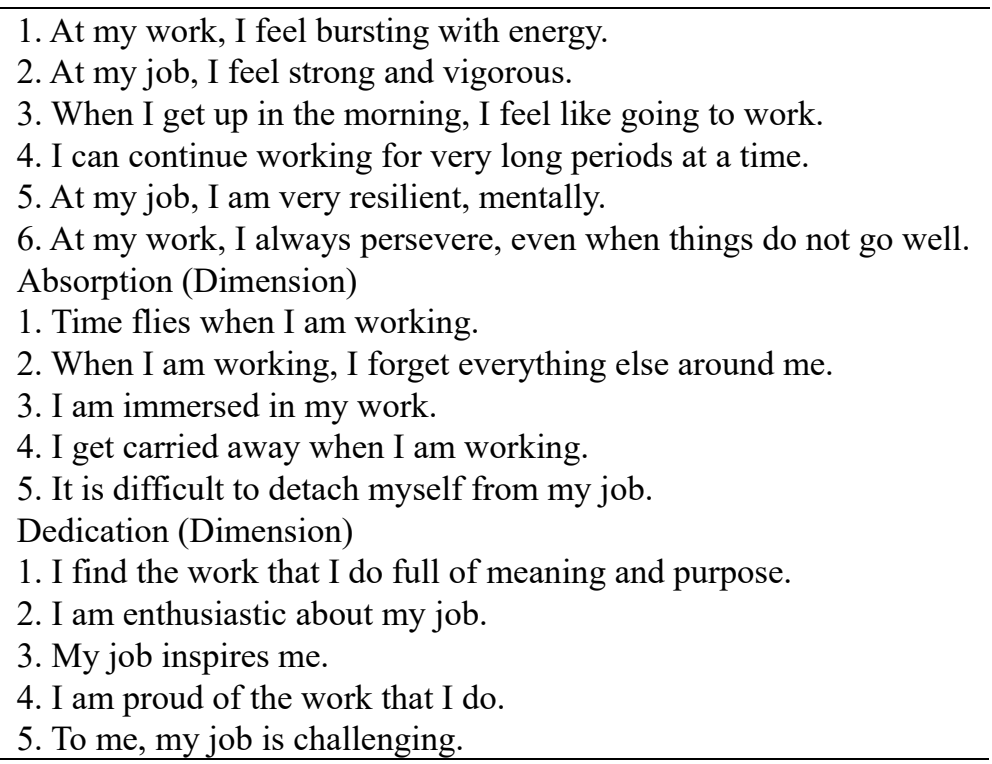

\subsubsection{Organization Performance (Dependent Variable)}

Organizational performance was operationalized using financial and non-financial Organizational performance. Financial Organizational Performance was operationalized using profitability, return on assets (ROA) and value added. While Non-Financial Organizational Performance was operationalized using managing clients, customer complaints, company reputation, productivity of employees and commitment issue. Organizational performance was measured using the dimensions of financial and non-financial performance. Table (2) shows the items used for each dimension. Financial performance was composed of 3 items derived from the study conducted by (Shahin et al., 2014) and non-financial performance was composed of 10 items derived from the study conducted by (Hernaus et al., 2012).

Table (2). Organizational Performance Measurements

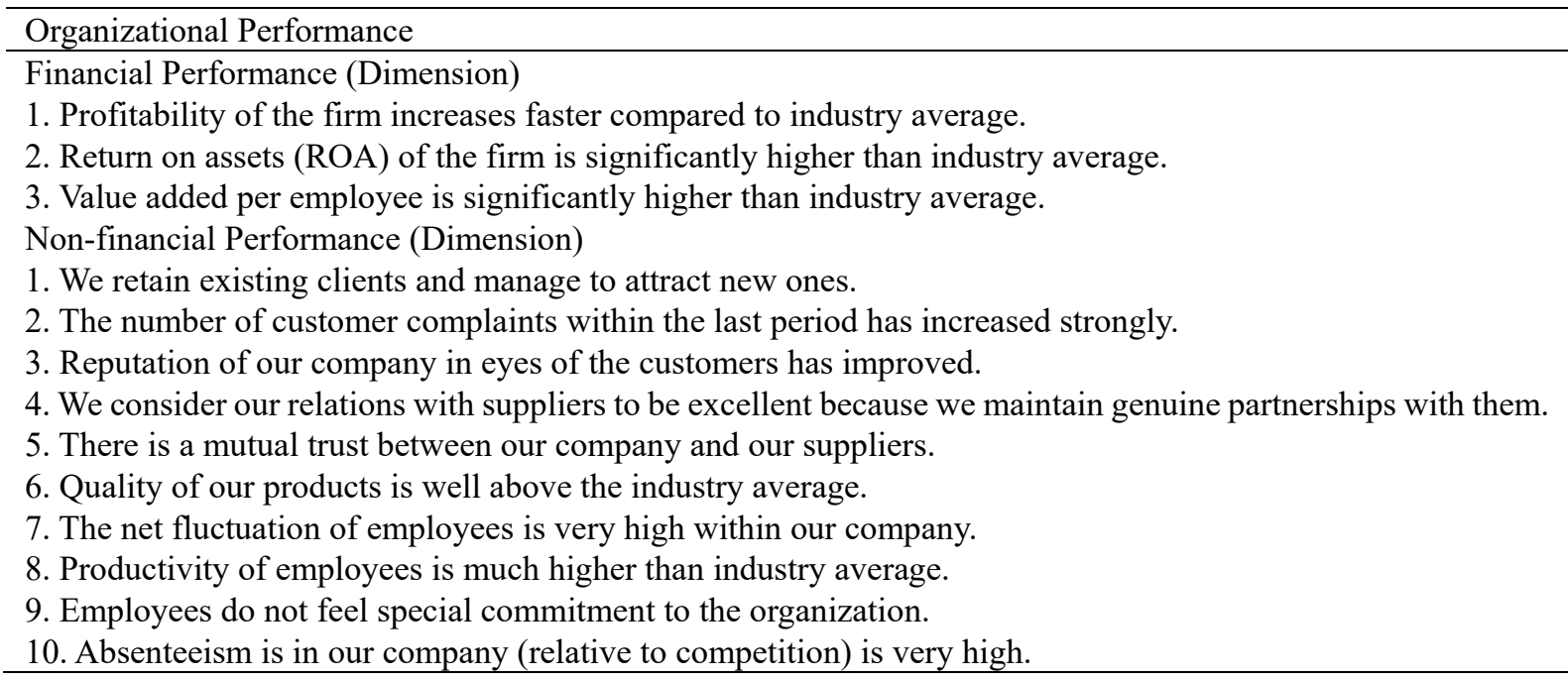

\subsubsection{Job Satisfaction (Mediating Variable)}

Job satisfaction was operationalized using intrinsic job satisfaction and extrinsic job satisfaction. Intrinsic job satisfaction was operationalized using desirable and challenging work assignments, recognition of achievement, responsibility, and advancement. They include items such as the freedom of employees to use their own judgment and being able to do things that don't conflict with their conscience (Stringer, 2006). Extrinsic job satisfaction was operationalized through factors such as supervision, interpersonal relations, physical working conditions, fair pay, co-workers, and job security (Stringer, 2006). Table (3) presents the questions used for each dimensions. Intrinsic 
job satisfaction was composed of 12 items and extrinsic job satisfaction was composed of 8 items derived from the study conducted by (Stringer, 2006).

Table (3). Job Satisfaction Measurements

Job Satisfaction

Intrinsic Job Satisfaction (Dimension):

On my present job, this is how I feel about:

1. Being able to keep busy all the time.

2. The chance to work alone on the job.

3. The chance to do different things from time to time.

4. The chance to be "somebody" in the community.

5. Being able to do things that don't go against my conscience.

6. The way my job provides for steady employment.

7. The chance to do things for other people.

8. The chance to tell people what to do.

9. The chance to do something that makes use of my abilities.

10. The freedom to use my own judgment.

11. The feeling of accomplishment I get from the job.

12. The chance to try my own methods of doing the job.

Extrinsic Job Satisfaction (Dimension):

On my present job, this is how I feel about:

1. The way my boss handles his/her personnel.

2. The competence of my supervisor in making decisions.

3. The way department policies are put into practice.

4. My pay and the amount of work I do.

5. The chances for advancement in this job.

6. The praise I get for doing a good job.

7. The working conditions.

8. The way my co-workers get along with each other.

Whereas all items were measured using a five-point rating scale, rating from one: "Strongly disagree", two: "Disagree", three: "Moderately agree", four: "Agree", to five: "Strongly agree".

\subsection{Research Model}

Research theoretical model is illustrated in figure (1) which clarifies the relationship between study variables.

Independent Variable

\section{Mediating Variable Dependent Variable}

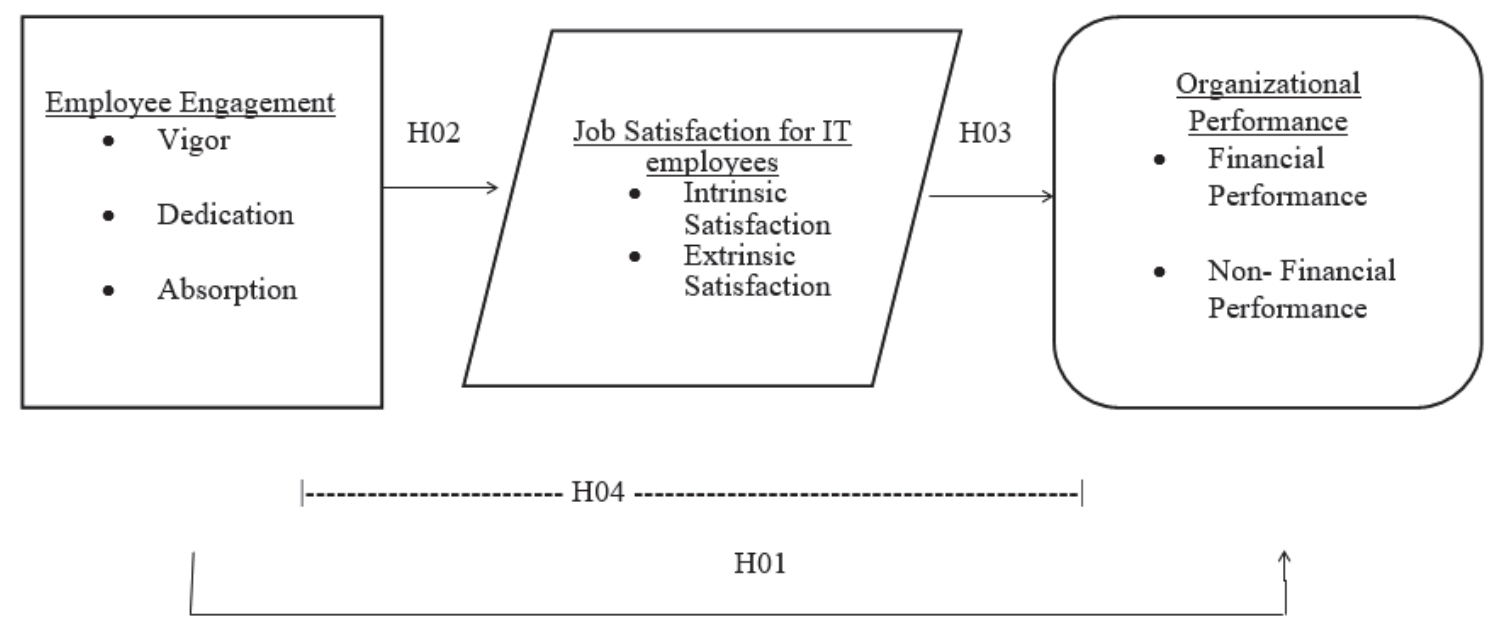

Figure (1). Research Model

\subsection{Research Hypotheses}

The principal and sub-hypotheses are set out below.

First Main Hypothesis: 
H01: There is no effect of Employee Engagement on Organizational Performance (at $\alpha$ level $<=0.05$ ).

H01 Sub- Hypotheses:

H01.1: There is no effect of Vigor on Organizational Performance (at $\alpha$ level $<=0.05$ ).

H01.2: There is no effect of Dedication on Organizational Performance (at $\alpha$ level $<=0.05$ ).

H01.3: There is no effect of Absorption on Organizational Performance (at $\alpha$ level $<=0.05$ ).

Second Main Hypothesis:

H02: There is no effect of Employee Engagement on Job Satisfaction (at $\alpha$ level $<=0.05$ ).

H02 Sub Hypotheses:

H02.1: There is no effect of Vigor on Job Satisfaction (at $\alpha$ level $<=0.05$ ).

H02.2: There is no effect of Dedication on Job Satisfaction (at $\alpha$ level $<=0.05$ ).

H02.3: There is no effect of Absorption on Job Satisfaction (at $\alpha$ level $<=0.05$ ).

Third Main Hypothesis:

H03: There is no effect of Job Satisfaction on Organizational Performance (at $\alpha$ level $<=0.05$ ).

H03 Sub- Hypotheses:

H03.1: There is no effect of Intrinsic Job Satisfaction on organizational Performance (at $\alpha$ level $<=0.05$ ).

H03.2:There is no effect of Extrinsic Job Satisfaction on organizational Performance (at $\alpha$ level $<=0.05$ ).

Fourth Main Hypothesis:

There is no mediating effect for Job Satisfaction on the relationship between Employee Engagement and Organizational Performance (at $\alpha$ level $<=0.05$ ).

\section{Methodology}

\subsection{Sample, and Data Collection}

Banks consider an important sector in economies by improving stability and increasing economic growth (AlFayoumi and Abuzayed, 2009; Obeidat et al., 2013). The Jordanian banking sector is composed of 25 banks as presented in table (4).

Table (4). Jordanian and non-Jordanian Banks Operating in Jordan at the End of 2015

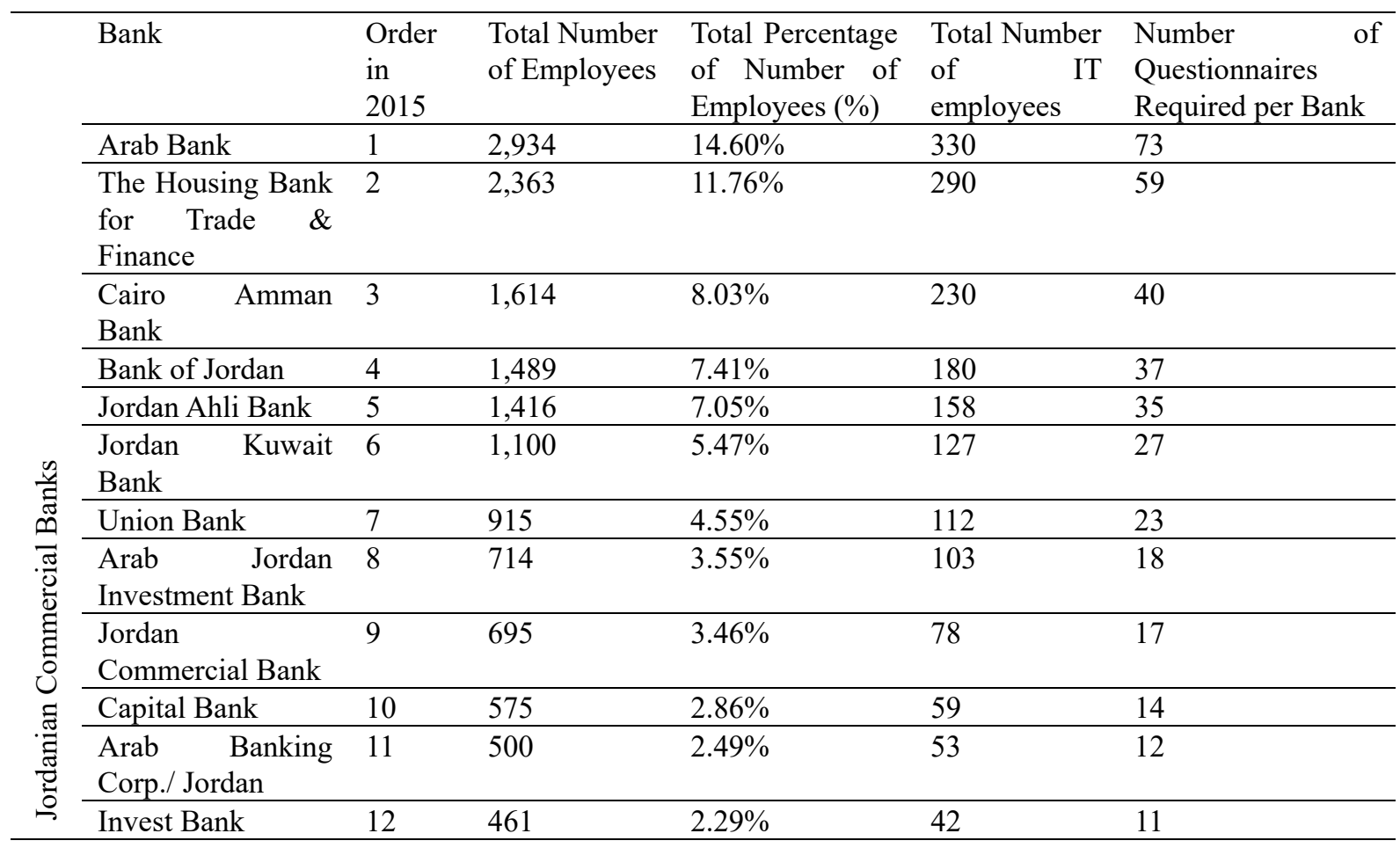




\begin{tabular}{|c|c|c|c|c|c|c|}
\hline & $\begin{array}{l}\text { Societe General - } \\
\text { Jordan }\end{array}$ & 13 & 257 & $1.28 \%$ & 34 & 6 \\
\hline \multirow{8}{*}{ 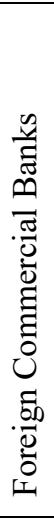 } & BLOM Bank & 1 & 382 & $1.90 \%$ & 41 & 10 \\
\hline & $\begin{array}{ll}\text { Egyptian } & \text { Arab } \\
\text { Land Bank } & \end{array}$ & 2 & 307 & $1.53 \%$ & 39 & 8 \\
\hline & Audi Bank & 3 & 269 & $1.34 \%$ & 37 & 7 \\
\hline & $\begin{array}{l}\text { Standard Chartered } \\
\text { Bank }\end{array}$ & 4 & 196 & $0.98 \%$ & 29 & 5 \\
\hline & $\begin{array}{l}\text { National Kuwait } \\
\text { Bank - Jordan }\end{array}$ & 5 & 98 & 0.49 & 21 & 2 \\
\hline & CITI Bank & 6 & 66 & $0.33 \%$ & 14 & 2 \\
\hline & $\begin{array}{l}\text { National Bank of } \\
\text { Abu Dhabi }\end{array}$ & 7 & 53 & $0.26 \%$ & 8 & 1 \\
\hline & Rafidain Bank & 8 & 19 & $0.09 \%$ & 3 & 0 \\
\hline \multirow{5}{*}{ 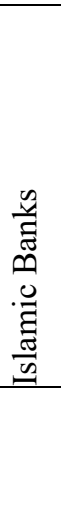 } & $\begin{array}{ll}\text { Jordan } & \text { Islamic } \\
\text { Bank } & \end{array}$ & 1 & 2,148 & $10.69 \%$ & 281 & 53 \\
\hline & $\begin{array}{l}\text { International Arab } \\
\text { Islamic Bank }\end{array}$ & 2 & 852 & $4.24 \%$ & 104 & 21 \\
\hline & $\begin{array}{lr}\text { Jordan } & \text { Dubai } \\
\text { Islamic } & \text { Bank } \\
\text { (Now: } & \text { Safwa } \\
\text { Bank) } & \\
\end{array}$ & 3 & 424 & $2.11 \%$ & 42 & 11 \\
\hline & Al-Rajhi Bank & 4 & 248 & $1.23 \%$ & 34 & 6 \\
\hline & $\begin{array}{l}\text { Total Number of En } \\
\text { working in the } \mathrm{J} \\
\text { Banking Sector }\end{array}$ & $\begin{array}{l}\text { iployees } \\
\text { ordanian }\end{array}$ & 20,095 & $100.00 \%$ & 2449 & 500 \\
\hline
\end{tabular}

Source: Association of Banks in Jordan (2016)

The goal of this study is to examine the effect of IT employee engagement on organizational performance through job satisfaction in the Jordanian banking sector. The IT employees working in the Jordanian banking sector served as the population for this research, who were reported to be 20,095 at the end of the year 2015 (Association of Banks in Jordan, 2016). Quota sampling was used to ensure that the various banks that make up the Jordanian banking sector were adequately represented in the study through the assignment of a quota. According to this, it can be seen in table (4) the appropriate sample that should be taken from each bank in order to reach the required sample size. Second, after determining the quota to be drawn from each bank, the researchers followed simple random sampling since the determined number of questionnaires to be distributed to each bank were given to the HR department and distributed at random.

In order to determine the appropriate sample size for this research based on the selected population, Sekaran and Bougie (2013) proposed a scientific guideline for sample size decision which was followed in this research. Based on the table prepared by Sekaran and Bougie (2013), the sample size for this research should be 377 IT Employees given that the population represents the total number of IT employees working in the Jordanian banking sector which is 2449 IT bank employees. However, this paper aimed to collect 500 questionnaires as stated in the above detailed table. Researchers gave out 500 questionnaires to the 25 banks and received 429 usable questionnaires. The remaining 71 questionnaires were deemed unusable. The Response rate was calculated and the result was $(429 / 500=85.8 \%)$.

\subsection{Validity and Reliability}

Validity tests how well the developed instrument measures the concepts it is supposed to measure, that is whether it measures the right concept or not (Sekaran and Bougie, 2013).

\subsubsection{Content Validity}

Content validity serves the assessment of whether the variables used to represent the concepts reflect accurately the content and definition of the needed concept (Bryman and Bell, 2015). To do that, the questionnaire was administered to participants-exactly the same way it will be administered in the main study- to fill them and provide their feedback in order to improve the internal validity of the questionnaire. As a result, the total numbers of 
questions were 49 questions. None of them were deleted or modified and the average time recorded to complete the questionnaire was six minutes which is considered reasonable.

\subsubsection{Construct Validity}

Construct validity is defined as "how well the results obtained from the use of the measure fit the theories around which the test is designed" (Sekaran and Bougie, 2013, p. 160). Sekaran and Bougie (2013) recommended factor analysis as a tool to investigate construct validity. Exploratory Factor Analysis (EFA) involves isolating factor structures without considering the theoretical expectations of the researcher (Thompson and Daniel, 1996). Responses to 49 questions employed in this research were obtained from respondents and subjected to principal axis factoring to assess dimensionality of the data. Three assumptions were followed to conduct EFA as suggested by Hair et al. (2010): sampling adequacy (Kiaser-Meyer-Olkin measure $>0.5$ ), the Eigen values for each factor should be $>1$, and a factor loading of 0.30 for each item is used as the threshold for item retention.

The results show that the Kiaser-Meyer-Olkin (KMO) index which ranges from (0) to (1) is $(0.896)$ for IT employee engagement, (0.920) for job satisfaction, and (0.738) for organizational performance which are all well above the recommended threshold suggested by Hair et al. (2010). The Bartlett's Test of Sphericity was statistically significant ( $p$-value $=0.000<0.05$ ) for all three variables indicating that the correlations are sufficiently large for factor analysis (Hair et al., 2010). KMO and Bartlett's Test of Sphericity are considered prerequisites for the extraction of the factors and are used to test the suitability of the data for factor analysis. Furthermore, a correlation matrix is introduced in the EFA process as a means of displaying the relationships between variables and is investigated for correlation coefficients over $(0.30)$. Quite a number of correlations greater than $(0.30)$ exist in this study, which indicates that factor analysis, are an appropriate statistical method to be used in this research.

The results revealed that all the factors had Eigen values greater than (1) and all the items had loadings greater that (0.30). Fulfilling the assumptions mentioned previously. A three-factor model of IT employee engagement emerged explaining $(68.101 \%)$ of the total variance which is above the (50-60\%) range suggested by Hair et al. (2010) for humanities studies. The pattern matrix which displays the rotated factor loadings is used to interpret the dimensions. The factors extracted coincide with the dimensions used in this study as can be seen in table (5). Items that load on the first dimension suggest that it represents Vigor and includes all 6 items used to measure it (VI1VI6), items that load on the second dimension suggest that it represents Absorption and includes all 5 items used to measure it (AB1-AB5), items that load on the third dimension suggest that it represents Dedication and includes all 5 items used to measure it (DE1-DE5).

Table (5). Pattern Matrix for IT Employee Engagement

\section{Pattern Matrix ${ }^{\mathrm{a}}$}

\begin{tabular}{llll} 
& \multicolumn{1}{l}{ Component } & 2 & 3 \\
\cline { 2 - 3 } VI1 & 1 & & \\
VI2 & .819 & & \\
VI3 & .873 & & \\
VI4 & .774 & & \\
VI5 & .864 & & \\
VI6 & .840 & .747 & \\
& .846 & .840 & \\
AB1 & & .813 & .784 \\
AB2 & & .849 & .815 \\
AB3 & & .801 & .774 \\
AB4 & & & .857 \\
AB5 & & & .791 \\
DE1 & & & \\
DE2 & & & \\
DE3 & & & \\
DE4 & & & \\
DE5 & & & \\
\hline
\end{tabular}

Extraction Method: Principal Component Analysis. 
Rotation Method: Promax with Kaiser Normalization.

All the items of job satisfaction were loaded without any deletion or addition. A two-factor model emerged explaining (53.696\%) of the total variance which is within the (50-60\%) range suggested by Hair et al. (2010). The factors extracted coincide with the dimensions used in this study as can be seen in table (6). Items that load on the first dimension suggest that it represents intrinsic job satisfaction and includes all 12 items used to measure it (IN1-IN12). Whereas the items were loaded on the second dimension suggest that it represents extrinsic job satisfaction and includes all 8 items used to measure it (EX1-EX8).

Table (6). Pattern Matrix for Job Satisfaction

Pattern Matrix ${ }^{\mathrm{a}}$

\begin{tabular}{lll}
\hline & Component & \\
\cline { 2 - 3 } IN1 & 1 & 2 \\
IN2 & & .341 \\
IN3 & & .532 \\
IN4 & & .617 \\
IN5 & & .829 \\
IN6 & & .885 \\
IN7 & & .876 \\
IN8 & & .895 \\
IN9 & & .820 \\
IN10 & & .433 \\
IN11 & & .479 \\
IN12 & & .470 \\
EX1 & & .572 \\
EX2. & .745 & \\
EX3 & & \\
EX4 & .865 & \\
EX5 & .872 & \\
EX6 & .690 & \\
EX7 & .793 & \\
EX8 & .595 & \\
\hline Extraction & .782 & \\
\hline
\end{tabular}

Extraction Method: Principal Component Analysis.

Rotation Method: Promax with Kaiser Normalization.

The items associated with organizational performance were loaded onto two factors indicating that none of the items were deleted. A two-factor model emerged explaining $(45.944 \%)$ of the total variance. The factors extracted reflectthe dimensions used in this study as can be seen in table (7). Items that were loaded on the first dimension suggest that it represents financial performance and includes all 3 items used to measure it (FP1-FP3). Items that were loaded on the second dimension suggest that it represents Non-financial performance and includes all 10 items used to measure it (NFP1-NFP10). From items (NFP2, NFP8, NFP9, and NFP10) showed factors loadings lower than 0.40 were deleted.

Table (7). Pattern Matrix for Organizational Performance

Pattern Matrix ${ }^{\mathrm{a}}$

\begin{tabular}{ll} 
Component & \\
\hline 1 & 2 \\
& .891 \\
.863 \\
.831
\end{tabular}




\begin{tabular}{ll} 
NFP1 & .669 \\
NFP2 & .301 \\
NFP3 & .821 \\
NFP4 & .853 \\
NFP5 & .724 \\
NFP6 & .737 \\
NFP7 & .535 \\
NFP8 & .308 \\
NFP9 & .129 \\
NFP10 & .132 \\
\hline EXFrion
\end{tabular}

Extraction Method: Principal Component Analysis.

Rotation Method: Promax with Kaiser Normalization.

Based on the results obtained from EFA it can be concluded that construct validity is confirmed. Indicating that the items used in this paper do in fact reflect what they were intended to measure.

\subsubsection{Reliability of Scales}

Reliability assesses the goodness of a measure and indicates the stability and consistency with which the instrument developed measures the concept (Sekaran and Bougie, 2013). Cronbach's alpha computed value range between 1 (perfect internal reliability) and 0 (no internal reliability) (Bryman and Bell, 2015). According to Hair et al. (2010), the minimum acceptable level of Cronbach's alpha for considering a study's instrument reliable should be 0.60 . The data were collected and analysed and the results obtained attested to the reliability of the instrument since all the measures had Cronbach's alpha coefficients of 0.60 and below (see table 8) as suggested by Hair et al. (2010). Based on the results, the researchers decided to keep all the questions to sustain the value of Cronbach's alpha.

Table (8). Cronbach's Alpha of Study Instrument based on Pilot Study

\begin{tabular}{lll}
\hline Variable & Number of Items & Cronbach's Alpha $(\alpha)$ \\
\hline IT Employee Engagement & 16 & 0.964 \\
Organizational Performance & 13 & 0.801 \\
Job Satisfaction & 20 & 0.935 \\
\hline
\end{tabular}

After collecting the final version of the questionnaire from the different banks, the Cronbach's alpha values were calculated for IT employee engagement, organizational performance and job satisfaction variables to determine the internal reliability. The results showed that the reliability of the IT employee engagement variables are higher than the accepted level; which is $(\alpha)$ is 0.60 , as mentioned in table 9 .

Table (9). Reliability Statistics for IT Employee Engagement

\begin{tabular}{lll}
\hline Variable & Cronbach's Alpha & No. of Items \\
\hline IT Employee Engagement & 0.902 & 16 \\
Vigor & 0.916 & 6 \\
Absorption & 0.871 & 5 \\
Dedication & 0.867 & 5 \\
\hline
\end{tabular}

The results of Cronbach's alpha values for the reliability of Job Satisfaction variables showed that they werehigher than the accepted level; which is $(\alpha)$ is 0.60 , as mentioned in table 10 . 
Table (10). Reliability Statistics for Job Satisfaction

\begin{tabular}{lll}
\hline Variable & Cronbach's Alpha & No. of Items \\
\hline Job Satisfaction & 0.922 & 20 \\
Intrinsic & 0.903 & 12 \\
Extrinsic & 0.879 & 8 \\
\hline
\end{tabular}

Finally, the results of Cronbach's alpha values for the reliability of Organizational performance variables showed that they werehigher than the accepted level; which is $(\alpha)$ is 0.60 , as mentioned in table 11 .

Table (11). Reliability Statistics for Organizational Performance

\begin{tabular}{lll}
\hline Variable & Cronbach's Alpha & No. of Items \\
\hline Organizational Performance & 0.717 & 13 \\
Financial & 0.896 & 3 \\
Non- Financial & 0.725 & 10 \\
\hline
\end{tabular}

\section{Results \& Discussion}

\subsection{Demographic Characteristics}

Demographic data provides the main attributes of the participating respondents which is included in the questionnaire instrument. These attributes include basic information about the respondents like age, gender, educational level, years of experience in banks and position. Table 12 shows the main attributes of the participating respondents.

Table (12). Respondents Demographic Profile

\begin{tabular}{|c|c|c|c|}
\hline Age & Frequency & Percent & Cumulative Percent \\
\hline Under 25 & 184 & 42.9 & 42.9 \\
\hline From 25 - Less than 36 & 194 & 45.2 & 88.1 \\
\hline From 36 - Less than 45 & 35 & 8.2 & 96.3 \\
\hline From 45 - Less than 54 & 11 & 2.5 & 98.8 \\
\hline 55 and over & 5 & 1.2 & 100.0 \\
\hline Total & 429 & 100.0 & \\
\hline Gender & Frequency & Percent & Cumulative Percent \\
\hline Male & 225 & 52.4 & 52.4 \\
\hline Female & 204 & 47.6 & 100.0 \\
\hline Total & 429 & 100.0 & \\
\hline Education & Frequency & Percent & Cumulative Percent \\
\hline Bachelor's Degree & 214 & 49.9 & 49.9 \\
\hline Higher Education Diploma & 143 & 33.3 & 83.2 \\
\hline Masters Degree & 61 & 14.2 & 97.4 \\
\hline PhD Degree & 5 & 1.2 & 98.6 \\
\hline Other & 6 & 1.4 & 100.0 \\
\hline Total & 429 & 100.0 & \\
\hline Experience & Frequency & Percent & Cumulative Percent \\
\hline Less than 3 years & 133 & 31.0 & 31.0 \\
\hline 3 - Less than 6 years & 135 & 31.5 & 62.5 \\
\hline 6 - Less than 9 years & 64 & 14.9 & 77.4 \\
\hline 9 years and above & 97 & 22.6 & 100.0 \\
\hline Total & 429 & 100.0 & \\
\hline Position & Frequency & Percent & Cumulative Percent \\
\hline IT Department Head & 137 & 31.9 & 31.9 \\
\hline IT Employee & 292 & 68.1 & 100.0 \\
\hline
\end{tabular}


As can be seen in the above table (12), the demographic profile of the respondents regarding gender shows that $(52.4 \%)$ of them were male and $(47.6 \%)$ female. This shows that the majority of respondents working in banks are males. With regards to age, the majority of respondents working in the banking sector (45.2\%) belong to the age group of 25-less than 36 years old, followed by (42.9\%) belonging to the age group less than 25 , $(8.2 \%)$ between 36 and less than $45,(2.5 \%)$ belong to the age group of 45 - less than 54 and finally $(1.2 \%)$ of them are older than 55 years old. The results showed that the majority of age groups in the Jordanian banks were under 36 years old representing youth respondents which equalled $(88.1 \%)$.

When considering the educational level of the respondents, it can be seen that the majority of them hold a bachelor's degree $(49.9 \%)$ and the rest of them are distributed in the other levels with $(33.3 \%),(14.2 \%),(1.2 \%)$ and $(1.4 \%)$ for higher education diploma, master's degree, $\mathrm{PhD}$ and other degrees such as college diploma or high school degree respectively. These results indicate that in order to be employed in a bank the basic educational requirement is a bachelor's degree with some exception for lower degrees in lower positions. Nowadays, pursuing higher education is mandatory for raising IT employees' salaries and positions in some banks. Most banks are encouraging their employees to pursue further education by providing full support in terms of loans, leaving work early, and taking days off.

In terms of experience, $(31.5 \%)$ of the respondents with 3-less than 6 years of experience, followed by (31\%) with less than 3 years of experience, $(22.6 \%)$ have over 9 years of experience, and $(14.9 \%)$ with 6-less than 9 years of experience. It is clear that large percentage of the respondents have primary experience in their field indicating that the work conditions, advancement, environment and benefits provided by banks result in high commitment. Finally with regards to position held by the IT employees who participated in the study, it was found that (31.9\%) of them were department heads. The remaining (68.1) of the respondents were regular IT employees. It can be concluded that the questionnaire reached and was answered by a representative IT employees working in Jordanian banks.

\subsection{Analysis of Multicollinearity}

Multicollinearity is defined as the degree to which the independent variables used in a multiple regression analysis are correlated (Zikmund et al., 2013; Ramadan et al., 2017). Multicollinearity reduces the ability to assess the individual importance of each independent variable. High levels of multicollinearity increase the probability that a good predictor of the outcome will be found non-significant and rejected from the model (Hair et al., 2010). In order to assess multicollinearity, both indicators of variance inflation factor (VIF) and tolerance were be used. Myers (1990) suggested that when the VIF is greater than 10 then it is a cause of concern. The tolerance statistic, which is the reciprocal of the VIF (1/VIF), is another important consideration when testing multicollinearity. To determine whether the current study suffers from multicollinearity, the researchers relied on a common cut off value of 0.10 for tolerance, and a value of 10 for VIF as recommended by Sekaran and Bougie (2013). Table (13) presents the VIF values for the independent variables used in this study, which ranged from 1.243-1.370, in addition to the tolerance values which ranged from $0.730-0.805$. These results indicate that no multicollinearity problem exists among the dimensions of the independent variable given that all the VIF values are below 10 and all the tolerance values are above 0.10 .

Table (13). The VIF and Tolerance Values for the Independent Variable

\begin{tabular}{lll}
\hline Variable & Tolerance & VIF \\
\hline Vigor & 0.730 & 1.370 \\
Absorption & 0.798 & 1.253 \\
Dedication & 0.805 & 1.243 \\
\hline
\end{tabular}

\subsection{Discussion}

Testing hypotheses aims to examine whether the null hypothesis is rejected in favor of alternative hypothesis. Statistically, the null hypothesis is considered true till the statistical techniques shows the opposite (Sekaran and Bougie, 2013). The decision rule that is concerned with null hypothesis test, is when the significance level ( $\mathrm{p}$ value) is less than .05 , the null hypothesis (H0) will be rejected and the alternative one will be accepted (HA) which indicates (a positive) effect, whereas the null hypothesis is accepted when the p-value is greater than .05.

\subsubsection{First Main Hypothesis}

H01: There is no effect of IT Employee Engagement on Organizational Performance (at $\alpha$ level<=0.05). 
The following table (14) presents the results of testing the first main hypothesis.

Table (14). Multiple Regression for the First Main Hypothesis

\begin{tabular}{|c|c|c|c|c|c|c|c|c|}
\hline & $\mathrm{R}$ & $\mathrm{R}^{2}$ & Adjusted $\mathrm{R}^{2}$ & F-value & Sig & Standardized Beta & t-value & Sig \\
\hline & 0.376 & 0.141 & 0.135 & 23.263 & $<0.001$ & & & \\
\hline Vigor & & & & & & 0.209 & 3.973 & $<0.001$ \\
\hline Absorption & & & & & & 0.165 & 3.270 & 0.001 \\
\hline Dedication & & & & & & 0.107 & 2.137 & 0.033 \\
\hline
\end{tabular}

The correlation coefficient $\mathrm{R}=0.376$ which indicates that the relationship between IT employee engagement and organizational performance is positive and that both variables change in the same direction. The coefficient of variation $\mathrm{R} 2$ shows that $14.1 \%$ of the variation in the dependent variable (organizational performance) is explained by the independent variable (IT employee engagement). The adjusted R2 indicates the generalizability of the model. It allows generalizing the results taken from the respondents to the whole population. It is noticed that the value of the adjusted $\mathrm{R} 2=0.135$ is close to the value of $\mathrm{R} 2=0.141$. If the adjusted $\mathrm{R} 2$ is excluded from $\mathrm{R} 2$ the value will be $(0.141-0.135=0.006)$. This amount of reduction means that if the whole population participates in the study and the model has been fitted then, there will be $0.60 \%$ less variance in the outcome. The analysis of variance (ANOVA) allows us to statistically test the main null hypothesis. The above table shows the results of the ANOVA test, where the F-ratio $=23.263$ and the $p$-value $<0.001$, this result indicates that there is less than $5 \%$ chance that an F-ratio of this value would occur solely by chance. Since the p-value $(<0.001)$ is smaller than the significance level (0.05), the null hypothesis is rejected and the alternative hypothesis is accepted indicating that IT employee engagement significantly affects organizational performance.

The results in the coefficients table revealed that all the dimensions of IT employee engagement significantly predicted organizational performance given that their significant betas were 0.209 for vigor, 0.165 for absorption and 0.107 for dedication. Therefore, the following decisions were made regarding the sub hypotheses of the first main hypothesis.

Table (15). Results of Testing the Sub Hypotheses for the First Main Hypothesis

\begin{tabular}{ll}
\hline Sub Hypotheses & Result \\
\hline $\mathrm{H}_{01.1}$ There is no effect of Vigor on Organizational Performance (at $\alpha$ level $\left.<=0.05\right)$. & Rejected \\
\hline $\mathrm{H}_{01.2}$ There is no effect ofDedicationon OrganizationalPerformance (at $\alpha$ level $\left.<=0.05\right)$. & Rejected \\
\hline $\mathrm{H}_{01.3}$ There is no effect ofAbsorptionon OrganizationalPerformance (at $\alpha$ level $<=0.05$ ). & Rejected \\
\hline
\end{tabular}

Employee engagement was found to have a positive impact on organizational performance in various studies such as Bakker and Schaufeli (2008); Bagnato and Paolino (2009); Gorgievski et al. (2010). The result obtained in this study is in accordance with the conclusions of previous studies, where IT employee engagement has a significant positive effect on organizational performance. This supports the notion that engagement is significantly related to a number of outcomes including commitment, health, turnover intentions, and performance (Halbesleben, 2010). According to Mone and London (2010), organizations that improve performance management can create and sustain high levels of employee engagement and in turn higher levels of performance.

It is evident that the energy and focus associated with engagement allow employees to bring their full potential to the job which improves the quality of their core work responsibilities (Anitha, 2014). Caplan (2013) suggested that employee engagement increases productivity and overall performance, creates a better and more productive work environment, and reduces non-attendance and turnover. Engaged employees want good communication with their superiors, work that has meaning for them and motivates them, and a safe working place. When these conditions are present, employees become engaged and as a result produce better financial results, are proud of their organizations, and demonstrate enthusiasm.

Unengaged employees, on the other hand, demonstrate poor customer service, lack of commitment, and poor performance. This may be attributed to the fact that their participation is lack luster, they do not excel, and do not care about the success of the organization (Shmailan, 2016). Regarding this study, the results suggest that bank employees believe that employee engagement improves organizational performance. According to them, feeling 
engaged and working in an environment that facilitates engagement allows them to show their full potential and excel in their work by cooperating with their colleagues, taking responsibility of their tasks, and trying to contribute fully to organizational goals and objectives, which ultimately results in high levels of performance.

Furthermore, the results of testing the sub-hypotheses for the first main hypothesis revealed that all the dimensions of IT employee engagement significantly predicted organizational performance. The results also showed that vigor contributed the most in predicting performance, followed by absorption and then dedication. Vigor implies high levels of energy and mental resilience while working. There is also a determined investment in the actual work, together with high levels of persistence in the face of difficulties (Shekari, 2015). According to Karatepe and Demir (2013) employees with high levels of vigor usually demonstrate willingness and persistence in investigating effort when performing their duties. Employees armed with vigor are motivated to excel in workplace duties regardless of the challenges faced (Salanova et al., 2005). Such employees are likely to perform better compared to employees without vigor, as they give their all in performing their tasks and are determined to get the job done regardless of what they encounter while doing so.

This motivation and persistence will eventually lead to high levels of organizational performance. Absorption refers to a sense of detachment from surroundings, a high degree of concentration on the job, and a general lack of conscious awareness of the amount of time spent on the job (Rayton and Yalabik, 2014). Employees experiencing absorption are engrossed in their work and find it difficult to detach themselves from the job (Shekari, 2015). Focusing all your efforts on completing tasks at hand and not paying attention to anything going around you allows you complete your work with minimum distraction and maximum effectiveness. As a result, employees who are absorbed in their work are generally better performers and contribute to the success of the organization. With regards to dedication, it is about being inspired, enthusiastic, and highly involved in one's job (Rayton and Yalabik, 2014).

Dedication is an individual's deriving sense of significance from work, feeling enthusiastic and proud about the given job, and feeling inspired and challenged by the job (Song et al., 2012). Employees who experience dedication are thus motivated to achieve organizational goals and reach targets which will improve the performance of the organization as a whole. In this study, employee engagement and improved organizational performance can be seen as ways for employees to repay the benefits received from the bank. That is, IT employees devote all the resources at their disposal (i.e. cognitive, emotional, and physical) to work roles by having high energy levels, being enthusiastic about their work, and being fully engrossed in their work.

\subsubsection{Second Main Hypothesis}

$\mathrm{H}_{02}$ : There is no effect of IT Employee Engagement on Job Satisfaction (at $\alpha$ level $<=0.05$ ).

The results of testing the second main hypothesis are demonstrated in table (16).

Table (16). Multiple Regression for the Second Main Hypothesis

\begin{tabular}{llllcllcc}
\hline & $\mathrm{R}$ & $\mathrm{R}^{2}$ & $\begin{array}{l}\text { Adjusted } \\
\mathrm{R}^{2}\end{array}$ & F-value & $\mathrm{Sig}$ & $\begin{array}{l}\text { Standardized } \\
\text { Beta }\end{array}$ & t-value & Sig \\
\hline Vigor & 0.483 & 0.234 & 0.228 & 43.187 & $<0.001$ & & & \\
Absorption & & & & & & 0.299 & 6.020 & $<0.001$ \\
Dedication & & & & & & 0.152 & 3.197 & 0.001 \\
\hline
\end{tabular}

The correlation coefficient $\mathrm{R}=0.483$ indicates that there is a positive correlation between IT employee engagement and job satisfaction as mentioned above. This proves that the independent variables and dependent variable change in the same direction. R square, coefficient of determination, represents the percentage of variance in the dependent variable that is explained by the variation in the independent variable (Sekaran and Bougie, 2013). The value of $\mathrm{R}^{2}=0.234$ indicates the amount of variations in job satisfaction that is accounted by the fitted model and has been explained by IT employee engagement.

The adjusted $\mathrm{R}^{2}$ indicates the generalizability of the model. It allows generalizing the results taken from the respondents to the whole population. It is noticed that the value of the adjusted $R^{2}=0.228$ is close to the value of $\mathrm{R}^{2}=0.234$. If the adjusted $\mathrm{R}^{2}$ is excluded from $\mathrm{R}^{2}$ the value will be $(0.234-0.228=0.006)$. This amount of reduction means that if the whole population participates in the study and the model has been fitted then, there will be $0.6 \%$ reduction in the variance of the outcome. 
The next step is the analysis of variance (ANOVA) that allows us to statistically test the main null hypothesis. The results of the ANOVA table show that the F-ratio $=43.187$ which is significant at level $p<0.05$ (sig. $<0.001$ ), this result indicates that there is less than 5\% chance that an F-ratio of this value would occur by chance alone. Since the $p$-value is smaller than the level of significance (0.05), the null hypothesis is rejected at $p<0.05$ significance level. As a result, it can be concluded that IT employee engagement affects job satisfaction in a statistically significant way.

Results from the coefficients table, the $\mathrm{t}$ and sig. (which is known as p-value) values, give a rough indication of the contribution of each predictor variable. A large absolute t-value and small $p$-value suggests that the predictor variable does contribute to the dependent variable. The results show that all the dimensions of employee engagement are significant contributors to job satisfaction ( $\mathrm{p}$-value $<0.05$ ). To measure the contribution of the predictor variables to the dependent variable, then standardized beta coefficient should be taken into consideration. A large value indicates that a unit change in this predictor variable has a large effect on the criterion variable (Sekaran and Bougie, 2013).

In this study vigor has the most contribution to job satisfaction with a $\beta$ of 0.299 . Dedication and absorption follow with $\beta$ values of 0.163 and 0.152 , respectively. Based on the results obtained from the multiple regression the following decisions can be made regarding the sub hypotheses of the second main hypothesis.

Table (17). Results of Testing the Sub Hypotheses for the Second Main Hypothesis

\begin{tabular}{ll}
\hline Sub Hypotheses & Result \\
\hline $\mathrm{H}_{02.1}$ There is no effect of Vigor on Job Satisfaction (at $\alpha$ level $\left.<=0.05\right)$. & Rejected \\
$\mathrm{H}_{02.2}$ There is no effect of Dedicationon Job Satisfaction (at $\alpha$ level $\left.<=0.05\right)$. & Rejected \\
$\mathrm{H}_{02.3}$ There is no effect of Absorptionon Job Satisfaction (at $\alpha$ level $\left.<=0.05\right)$. & Rejected \\
\hline
\end{tabular}

The results of the second main hypothesis revealed that IT employee engagement has a significant positive effect on job satisfaction. This result falls in line with the conclusions of Harter et al. (2002), Schaufeli and Bakker (2004), Radosevich et al. (2008), Schaufeli et al. (2009), Wefald and Downey (2009), and Alarcon and Edwards (2011), where employee engagement was found to influence several work outcomes including job satisfaction. This may be due to the fact that engagement has been described as a fulfilling, positive work-related experience and state of mind and thus results in good health and positive work outcomes (Schaufeli and Bakker, 2004). Schaufeli and Bakker (2004) noted that engaged employees are more likely to be engaged to their organization and have a lower tendency to leave their organization (Saks, 2006). Radosevich et al. (2008) also supported this conclusion as they argued that highly engaged employees have higher job satisfaction when compared to disengaged employees.

In addition, Saks (2006) suggested that highly engaged employees are more likely to demonstrate positive attitudes, intentions and behaviours within the work environment. This result indicates that IT bank employees in Jordan believe that being engaged in their work will make them more satisfied with their job and less likely to leave the bank. As such IT employees who experience vigor, absorption, and dedication are more likely to be satisfied with their jobs. This is supported by the findings of this study since vigor, absorption, and dedication were found to be significant predictors of job satisfaction, with vigor being having the highest predictive power. Vigor relates to having high energy levels, resilience, willingness to invest effort, and persistence in the face of challenges.

As such IT employees working in the Jordanian banking sector believe that when they are energized, have resilience, willing to exert effort in performing their jobs, and are persistent, they will be more satisfied with their jobs. This is because IT employees, who are vigorous, are happy to be going to work and have positive vibes making them eager to perform their job and feel sense of fulfilment while doing it, thus satisfied with their current situation.

According to the Affective Events Theory (AET) (Weiss and Cropanzano, 1996), job conditions lead to affective reactions which eventually lead to job satisfaction and other work-related attitudes. AET further suggests that when job-related situations continuously evoke certain felt emotions, an individual's affective mode becomes stable, leading to specific and foreseeable attitudes and behaviors including job satisfaction (Weiss et al., 1999), which could be considered an explanation for how vigor influences job satisfaction. Another explanation can be related to the Affect Infusion Model (AIM), which postulates that affect has a direct impact on individuals' cognitive and behavioral processes (Forgas and George, 2001).

This model indicates that IT employees' job satisfaction is partially a function of the affect that infuses their 
cognitive processing in forming their evaluation. Prior studies have supported the notion that individuals' affective states may predict a wide range of evaluative judgments, including job satisfaction such as Fisher (2000) and Judge and Ilies (2004). Also, based on the responses obtained in the current study, the dimension of dedication holds second place in determining the satisfaction levels of IT bank employees, indicating that energy and effort in performing the job (i.e. vigor) are more important than being involved in the job (i.e. dedication).

\subsubsection{Third Main Hypothesis}

$\mathrm{H}_{03}$ : There is no effect of IT Job Satisfaction on Organizational Performance (at $\alpha$ level $<=0.05$ ).

The results of testing the thirdmain hypothesis are demonstrated in table (18).

Table (18). Multiple Regression for the Third Main Hypothesis

\begin{tabular}{|c|c|c|c|c|c|c|c|c|}
\hline & $\mathrm{R}$ & $\mathrm{R}^{2}$ & Adjusted $\mathrm{R}^{2}$ & F-value & Sig & $\begin{array}{l}\text { Standardized } \\
\text { Beta }\end{array}$ & t-value & Sig \\
\hline & 0.463 & 0.215 & 0.211 & 58.176 & $<0.001$ & & & \\
\hline Intrinsic & & & & & & 0.320 & 6.120 & $<0.001$ \\
\hline Extrinsic & & & & & & 0.200 & 3.824 & $<0.001$ \\
\hline
\end{tabular}

The correlation coefficient $\mathrm{R}=0.463$ indicates that there is a positive correlation between job satisfaction and organizational performance. This positive relationship suggests that the independent variable and dependent variable move in the same direction. The value of $\mathrm{R}^{2}=0.215$ indicates the amount of variations in organizational performance that is accounted by the fitted model and has been explained by job satisfaction. The adjusted $\mathrm{R}^{2}$ indicates the generalizability of the model.

It allows generalizing the results taken from the respondents to the whole population. It is noticed that the value of the adjusted $R^{2}=0.211$ is very close to the value of $R^{2}=0.215$. If the adjusted $R^{2}$ is excluded from $R^{2}$ the value will be $(0.215-0.211=0.004)$. This amount of reduction means that if the whole population participates in the study and the model has been fitted then, there will be $0.4 \%$ less variance in the outcome. The analysis of variance (ANOVA) allows us to statistically test the main null hypothesis. The results show that the F-ratio $=58.176$ and $\mathrm{p}$ value $<0.001$, this result indicates that there is less than $5 \%$ chance that an F-ratio of this value would occur solely by chance. Since the $\mathrm{p}$-value is smaller than the level of significance $(0.05)$, the null hypothesis is rejected at $\mathrm{p}<$ 0.05 significance level.

Hence, job satisfaction significantly affects organizational performance. The results obtained from the coefficients tableindicate that intrinsic job satisfaction contributes the most to organizational performance given that $\beta=0.320$. Extrinsic job satisfaction, on the other hand, contributes less to organizational performance with a $\beta$ of 0.200 . Based on the results of conducting the multiple regression analysis for the third main hypothesis the following decisions can be made regarding the sub hypotheses.

Table (19). Results of Testing the Sub Hypotheses for the Third Main Hypothesis

\begin{tabular}{ll}
\hline Sub Hypotheses & Result \\
\hline $\mathrm{H}_{03.1}$ There is no effect ofIntrinsic Job Satisfaction on Organizational Performance (at $\alpha$ level & Rejected \\
$<=0.05)$. & \\
$\mathrm{H}_{03.2}$ There is no effect ofExtrinsic Job Satisfaction and Organizational Performance (at $\alpha$ level & Rejected \\
$<=0.05)$. &
\end{tabular}

The results of testing the third main hypothesis revealed that job satisfaction had a significant positive effect on organizational performance. Previous studies have indicated positive association between job satisfaction and organizational performance (e.g. Ellinger et al., 2002; Koys, 2003; Latif et al., 2013) which is supported by this study. The reason behind reaching this conclusion is that IT employees who have high levels of job satisfaction generally love their job; feel justice in the environment in which they work, and feel that their jobs provides them with variety, challenge, good pay, job security, autonomy, pleasant co-workers, etc.

When IT employees feel happy at work, they are willing to go above and beyond call of duty by devoting private time to their work activities, exert creativity, become more committed to their organization, seek ways to overcome obstacles which might influence realisation of their jobs, and assist their colleagues and superiors. These employees will have superior performance and organizations with these kinds of employees will be successful. 
According to Surujlal and Singh (2003) and Yee et al. (2008) management should pay close attention on creating a work environment that facilitates higher employee satisfaction levels since satisfaction can stimulate loyalty and confidence in employees, improves quality of outputs, and increases productivity.

Satisfied employees tend to perceive that the organization will be more satisfying in the long run, they care about the quality of their work and are more committed to the organization, leading to a demonstration of organizational citizenship behaviours (Fraser, 2001; Sempane et al., 2002; Yoon and Suh, 2003). Goslin (2005) also stated that satisfied employees have higher retention rates and are more productive. When employees are dissatisfied, their physical and mental health is negatively affected (Faragher et al., 2005).

As a result, organizational performance will also deteriorate as more production time will be lost as dissatisfied employees are likely to take more leave (Judge et al., 2010; Shields, 2006); therefore, if steps are taken to improve employee satisfaction, overall success of the organization is enhanced and the results can be reflected through happier employees, enhanced workforce productivity, reduced workdays and higher profits. Other researchers, however, contradict the findings of this study by stating that an insignificant relationship exists between job satisfaction and organizational performance (Daily and Near, 2000; Mohr and Puck, 2007), or that job satisfaction does not affect organizational performance (Kanyurhi and Akonkwa, 2016).

With regards to this study, this conclusion suggests that banks operating in the Jordanian banking sector should ensure that their IT employee are satisfied on an on-going basis in order to improve overall performance of the bank. The literature confirms that satisfied employees do perform better and contribute to the overall success of an organization. On the other hand, employees who are not satisfied do not perform well and become a barrier to success. This research suggests that this is a global phenomenon and by focusing on improving satisfaction and performance, organizations can be more successful. As a result, it is in the best interest of banks to determine ways to improve IT employees' job satisfaction.

Moreover, the results of this study indicated that intrinsic job satisfaction had the most power in predicting organizational performance followed by extrinsic job satisfaction. This suggests that IT bank employees believe that intrinsic factors are more important for them in determining their satisfaction levels and in turn the level of performance in the bank. These factors include desirable and challenging work assignments, recognition of achievement, responsibility, advancement, and freedom to use own judgement. For example, Clark (2001) acknowledged that if a job is interesting and provides the opportunity to use one's skills, then the employee is bound to enjoy the job and forget about leaving the organization.

Furthermore, utilizing abilities in doing a job facilitates the recruitment and retention of employees and helps the organization by benefiting from improved motivation and excellent business performance (SQW Consulting, 2010). Employees who feel their abilities are under-utilized, on the other hand, become de-motivated and may seek employment elsewhere, resulting in increased employee turnover in the organization (Hassanain, 2006). As such it is safe to say that increased opportunities for members of the department or team to apply their abilities may result in higher levels of organizational performance within the organization. In addition, the degree to which a job provides substantial freedom, independence and discretion of the employee in his or her job (autonomy) influences the level of job satisfaction that the employee experiences (Brunetto and Farr-Wharton, 2004). Giving task autonomy to employees is generally expected to result in higher motivation, satisfaction, and performance (Langfred and Moye, 2004).

Conversely, unwillingness to give autonomy due to centralising tendencies, risk-averse behaviours and an uncertain policy environment results in decreased organizational performance. Nonetheless, extrinsic factors, including supervision, interpersonal relations, physical working conditions, fair pay, co-workers, and job security, shouldn't be ignored as they also play an important role in predicting performance. For example, working conditions have been reported to have a positive impact on IT employee and job-related outcomes such as worker's welfare, health, team spirit, morale, efficiency, and productivity (Koonmee et al., 2010). In contrast, poor working conditions make employees uncomfortable, thereby reducing the pace of work. This situation may demand extra efforts to keep everything organized, which results in wasted time.

In addition, inconvenient timetables influence labour productivity in that repetitive long working hours get workers exhausted (Chadha, 2007). Moreover, poor working conditions also lead to the deterioration of the relationships between managers and employees (Estes and Wang, 2008). Such an unfriendly atmosphere may undermine selfesteem, co-operation and the ability of employees to come up with creative ideas. Thus, working conditions can be seen as an instrumental factor in enhancing the performance of both the individual employee as well as the organization in general. Job security has also been reported to have an effect on overall organizational performance.

Organizations that offer low job security cause their employees to lose faith in their future in the organization 
which consequently affects performance. Whereas employees that enjoy high job security are more likely to perform their tasks effectively this is reflected on the organization's performance (Lucky et al., 2013).

\subsubsection{Fourth Main Hypothesis}

$\mathrm{H}_{04}$ : There is no mediating effect for Job Satisfaction on the relationship between IT Employee Engagement and Organizational Performance (at $\alpha$ level $<=0.05$ ).

Mediation is a hypothesized causal chain in which one variable affects a second variable that, in turn, affects a third variable. Graphically, mediation can be depicted in the following way (Sekaran and Bougie, 2013):

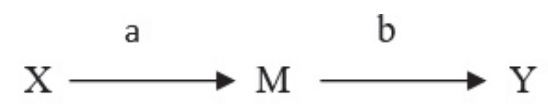

Paths (a) and (b) are called direct effects, the mediational effect in which $\mathrm{X}$ leads to $\mathrm{Y}$ through $\mathrm{M}$, is called the indirect effect (UPA, 2015). In order to test for mediation Baron and Kenny (1986) proposed a four step approach in which several regression analyses (simple and multiple) are conducted and the significance of the coefficients is examined at each step. A detailed explanation of the approach proposed by Baron and Kenny (1986) is presented in table (20).

Table (20). Steps for Testing Mediation

\section{Analysis}

Step 1 Perform a simple regression analysis with $\mathrm{X}$ predicting $\mathrm{Y}$ to test for path c alone, $\mathrm{Y}=\mathrm{B}_{0}+\mathrm{B}_{1} \mathrm{X}+\mathrm{e}$

Step 2 Perform a simple regression analysis with $\mathrm{X}$ predicting $\mathrm{M}$ to test for path $\mathrm{a}, \mathrm{M}=\mathrm{B}_{0}+\mathrm{B}_{1} \mathrm{X}+\mathrm{e}$

Step 3 Perform a simple regression analysis with $\mathrm{M}$ predicting $\mathrm{Y}$ to test the significance of path $\mathrm{b}$ alone, $\mathrm{Y}=\mathrm{B}_{0}+\mathrm{B}_{1} \mathrm{M}+\mathrm{e}$

Step $4 \quad$ Perform a multiple regression analysis with $\mathrm{X}$ and $\mathrm{M}$ predicting $\mathrm{Y}, \mathrm{Y}=\mathrm{B}_{0}+\mathrm{B}_{1} \mathrm{X}+\mathrm{B}_{2} \mathrm{M}+\mathrm{e}$
Visual depiction
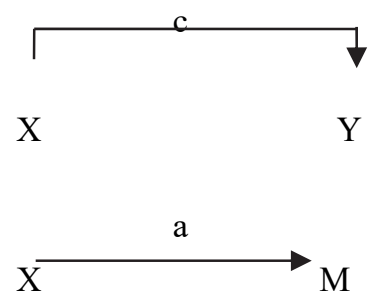

b
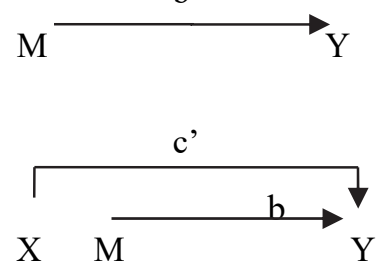

Steps 1-3 establish whether zero-order relationships among the variables exist. If one or more of these relationships are non-significant, researchers usually conclude that mediation is not possible or likely (MacKinnon et al., 2007). Assuming there are significant relationships from Steps 1 through 3, one proceeds to Step 4. In the Step 4 model, some form of mediation is supported if the effect of $\mathrm{M}$ (path $\mathrm{b}$ ) remains significant after controlling for $\mathrm{X}$. If $\mathrm{X}$ is no longer significant when $\mathrm{M}$ is controlled, the finding supports full mediation.

If $\mathrm{X}$ is still significant (i.e., both $\mathrm{X}$ and $\mathrm{M}$ both significantly predict $\mathrm{Y}$ ) but its coefficient is reduced in value, then the finding supports partial mediation (UPA, 2015). A combination of simple and multiple regression analyses were conducted as proposed by Baron and Kenny (1986) in an effort to test the fourth main hypothesis. The results of the regression tests were summarized in table (21). It is worth noting that the Baron and Kenny (1986) model of mediation focuses on the unstandardized regression coefficients, therefore, the coefficients mentioned in the below table represent the unstandardized betas. 
Table (21). Regression Analysis for Mediation of IT Employee Engagement on Organizational Performance through Job Satisfaction

\begin{tabular}{lllll}
\hline Variables & $\begin{array}{l}\text { Step 1 } \\
\text { Organizational } \\
\text { Performance }\end{array}$ & $\begin{array}{l}\text { Step 2 } \\
\text { Job Satisfaction }\end{array}$ & $\begin{array}{l}\text { Step 3 } \\
\text { Organizational } \\
\text { Performance }\end{array}$ & $\begin{array}{l}\text { Step 4 } \\
\text { Organizational } \\
\text { Performance }\end{array}$ \\
(Constant) & $2.220^{* *}$ & $1.901^{* *}$ & $1.964^{* *}$ & $1.604^{* *}$ \\
IT Employee Engagement & $0.330^{* *}$ & $0.468^{* *}$ & & $0.179^{* *}$ \\
Job Satisfaction & & & $0.411^{* *}$ & $0.324^{* *}$ \\
$\mathrm{R}$ & 0.372 & 0.476 & 0.455 & 0.488 \\
$\mathrm{R}^{2}$ & 0.139 & 0.226 & 0.207 & 0.238 \\
Adj. $\mathrm{R}^{2}$ & 0.137 & 0.224 & 0.205 & 0.235 \\
F-value & $68.708^{* *}$ & $124.891^{* *}$ & $111.455^{* *}$ & $66.672^{* *}$ \\
\hline
\end{tabular}

$* * \mathrm{p} \leq 0.05$.

To determine whether job satisfaction mediates the relationship between IT employee engagement and organizational performance the following rule was acted upon: some form of mediation is supported if the effect of the expected mediator remains significant after controlling for the independent variable. If the independent variable is no longer significant when the expected mediator is controlled, the finding supports full mediation. If the independent variable is still significant (i.e., both the independent variable and the expected mediator both significantly predict the dependent variable), the finding supports partial mediation.

Furthermore, the strength of the independent variable in predicting the dependent should be reduced in the presence of the mediator variable in order to support partial mediation (Baron and Kenny, 1986). Based on this, partial mediation exists since IT employee engagement and job satisfaction both significantly predict organizational performance ( $\mathrm{p}$-values $>0.001$ ) and the value of unstandardized beta for IT employee engagement was reduced from 0.330 to 0.179 .

Although Baron and Kenny (1986) provide an interesting approach to follow in order to determine the presence or absence of a mediation effect, it is considered necessary to conduct a formal significance test of the indirect effect if the Baron and Kenny criteria have been met. Baron and Kenny (1986) describe a procedure developed by Sobel (1982) that assesses more directly the indirect effect of mediation. The Sobel test is performed by comparing the strength of the indirect effect of $\mathrm{X}$ on $\mathrm{Y}$ to the point null hypothesis that it equals zero. The indirect effect of $\mathrm{X}$ on $\mathrm{Y}$ in this situation is defined as the product of the $\mathrm{X} \longrightarrow \mathrm{M}$ path (a) and the $\mathrm{M} \longrightarrow \mathrm{Y}$ path (b), or (ab). In most situations, $a b=\left(c-c^{\prime}\right)$, where $c$ is the simple (i.e., total) effect of $X$ on $Y$, not controlling for $M$, and $c^{\prime}$ is the $\mathrm{X} \longrightarrow \mathrm{Y}$ path coefficient after the addition of $\mathrm{M}$ to the model.

To calculate the indirect effect according to Sobel (1982), the unstandardized regression coefficient obtained from regressing the mediator to predict the dependent variable (adjusting for the independent variable) $(\beta=0.411)$ should be multiplied by the unstandardized regression coefficient obtained from regressing the independent variable to predict the mediator $(\beta=0.468)$. Thus, the indirect effect of IT employee engagement on organizational performance through job satisfaction $=0.411 * 0.468=0.192$. In order to ensure that the indirect effect is significant, it is recommended to run Sobel test (Sobel, 1982).

The Sobel test requires the computation of the raw regression coefficient (unstandardized coefficients) and the standard error for this regression coefficient for the association between the independent variable and the mediator (path a), and the association between the mediator and the dependent variable (adjusting for the independent variable, path $b$ ). The unstandardized $\beta$ for path $(a)=0.468$ and the standard error $=0.042$, and for path (b) unstandardized $\beta=0.411$ and the standard error $=0.039$. The data are then entered into the following program to calculate the Sobel test value.

\begin{tabular}{|c|c|c|c|c|}
\hline Input: & & Test statistic: & Std. Error: & $p$-value: \\
\hline a 0.468 & Sobel test: & 7.6565726 & 0.02512195 & 0 \\
\hline b 0.411 & Aroian test: & 7.64034914 & 0.02517529 & 0 \\
\hline$s_{a} 0.042$ & Goodman test: & 7.67289986 & 0.02506849 & 0 \\
\hline$s_{\mathrm{b}} 0.039$ & Reset all & & Calculate & \\
\hline
\end{tabular}


The results showed that the null hypothesis should be rejected and the alternative hypothesis should be accepted since the p-value for the Sobel test $(<0.001)$ falls below the established alpha level of 0.05 , indicating that the association between IT employee engagement and organizational performance is mediated by job satisfaction. Regarding the fourth hypothesis, the results indicated that job satisfaction partially mediates the link between employee engagement and organizational performance. This finding cannot be verified empirically by comparing it to other studies as this study is regarded as one of the few attempting to investigate the presence of a third variable, specifically job satisfaction, between IT employee engagement and organizational performance.

Although job satisfaction was expected to fully mediate the link between engagement and performance, the results only suggested partial mediation which is in line with the conclusion reached by Baron and Kenny (1986) who stated that having a partial mediation model is more realistic in most social science research as a single mediator cannot be expected to completely explain the relationship between the independent variable and the dependent variable. Such a result suggests that IT employee engagement relies to a certain extent on the presence of a third variable to have an effect on organizational performance.

It further suggests that although each variable (i.e. IT employee engagement and job satisfaction) contributes significantly to organizational performance on its own, when combined this contribution is at its highest. This is attributed to the fact that IT employees who are engaged are likely to experience feeling of fulfilment on the job due to their high level of energy, enthusiasm, and involvement which results in them being satisfied and in turn results in positive work outcomes. Based on this result it can be noted that the satisfaction of employees working in the IT Departments within Jordanian banking sector partially aids in transporting the effect of employee engagement on to organizational performance.

\section{Conclusion}

This study examined job satisfaction among Information Technology (IT) employees in banking sector, this service sector is one of the most important sectors in the Jordanian economy, where banks are ranked among the top service providing organizations. As a result, these organizations require the presence of engaged, loyal, and committed IT employees who are prepared to provide the highest level of service they could offer in order to achieve the organization's objectives. However, some of these organizations are faced with the challenge of having disengaged and dissatisfied IT employees, and as a result their performance suffers tremendously. The goal of this study was to determine whether IT employee engagement had an effect on organizational performance through the mediating role of job satisfaction. This research sets itself apart from previous research by using job satisfaction as a mediator between employee engagement and organizational performance, given that previous work only focused on the dual effect of the variables mentioned.

The results of testing the hypotheses showed that the first main hypothesis was rejected indicating that IT employee engagement significantly affected job satisfaction. The beta coefficients obtained indicated that all the dimensions of IT employee engagement contributed to job satisfaction with vigor having the most contribution. The results of testing the second main hypothesis revealed that job satisfaction had a significant positive effect on organizational performance. Furthermore, it was found that both of the dimensions of job satisfaction predicted organizational performance with intrinsic job satisfaction having the most predictive power.

The third main hypothesis was rejected suggesting that IT employee engagement significantly affected organizational performance, with vigor having the most contribution. In order to test the fourth main hypothesis the Baron and Kenny (1986) mediation model was adopted. The results of testing the mediating effect of job satisfaction on the association between IT employee engagement and organizational performance supported only partial mediation. The Baron and Kenny (1986) mediation model does not necessarily indicate that an indirect effect exists; therefore, the researchers conducted a Sobel (1982) test for the indirect effect. The results of the Sobel test showed that an indirect effect does exist and that job satisfaction does have a mediating role between IT employee engagement and organizational performance.

In conclusion, the current paper has provided support that all the variables significantly affected each other. Furthermore, it provided support for the ability of job satisfaction to mediate the engagement-performance relationship. Thus, this study and its findings have a number of contributions and implications.

\subsection{Research Contribution}

The current study was conducted based on existing literature, however, each of the previous researches was done in a different context (i.e. country, industry, department), where employees think and behave differently according to the situation they face. Therefore, this study contributes to enabling others to understand the effect of IT employee engagement on job satisfaction, job satisfaction on organizational performance, and IT employee 
engagement on organizational performance in the Jordanian banking sector since few studies have been conducted to examine this topic in this particular department and this particular industry besides this particular country.

Traditionally, studies have focused on examining the dual effect of employee engagement or job satisfaction on organizational performance and have devoted limited attention to studying the mediating or moderating effect of one of another variable. Thus, this study went a step further by not only studying the dual effect of the variables chosen, but also examining the mediating role of job satisfaction in an effort to enrich existing literature.

\subsection{Research Implications}

The current paper was built on relevant published work and developed a research model which aims at the investigation of the mediating effect of job satisfaction on the link between employee engagement and organizational performance. Reviewing existing literature revealed that similar studies have not been undertaken in the IT departments and Jordanian banking sector. Therefore, in addition to the contribution of this study to theoretical development, the useful findings produced can be utilized by bank managers towards the development and implementation of practices that will lead to improved organizational performance.

\subsubsection{Theoretical implications}

The theoretical implications of this study are fivefold: first, our study contributes to the IT and business literature by introducing new model as an important alternative theoretical model through which to gain an understanding of IT employees satisfaction within banking sector. In doing so, our study theorizes and empirically validates the crucial mediating role of IT employees job satisfaction in formulating organization performance. Over and beyond the already better agreed relationship between employees' engagement and organization performance.

Specifically, the results advance the scholarly understanding of IT employees engagement and job satisfaction as key antecedents to organization performance. Second, this study showed that job satisfaction can be used to transfer the effect of employee engagement on organizational performance. Third, this study contributed to the job satisfaction literature by showing how employee engagement, in terms of vigor, absorption, and dedication, can be used to increase the employees' satisfaction with their jobs. Fourth, the model developed in this study and subsequent hypotheses could be used and improved on by other scholars with similar research interests. Finally, this study will enrich the IT and organizational performance literature for the developing countries more specifically for Jordan.

\subsubsection{Practical Implications}

First, the managerial implications of this study are fourfold: first, the results of this study can aid managers in comprehending how IT employee engagement can improve job satisfaction. Bank managers can search for and adopt tools that can increase the engagement of their IT employees, if they want their employees to be satisfied and invested in the work they do, since committed, and involved IT employees are more willing to put forth their efforts in order to achieve the organization's goals and objectives.

Second, managers should make it a priority to create a working environment that facilitates the satisfaction of organizational IT employees. Having satisfied IT employees, means having loyal and committed IT employees who are willing to do anything for the organization they work for. To ensure the satisfaction of bank IT employees, managers can implement strategies to improve career growth, recognition, trust between IT employees and senior management, and personal status. Furthermore, reviewing pay and compensation schemes, benefits, and job security of banks should be at the top of managers' lists as they play an important role in determining the satisfaction levels of IT employees. Although compensation/pay, benefits and job security shape the degree to which IT employees are satisfied, it is also noteworthy to mention that the extent of their importance fluctuates as a result of external factors such as changing economic conditions (SHRM, 2016).

Third, the findings assist in explaining how the level of engagement exerted by IT employees can affect the performance levels of the banks in which they operate. This implies that managers that focus on improving the engagement levels of their IT employees will enjoy improved organizational performance. Managers should thus understand that having appropriate policies, procedures, structures, and systems in place will help increase the engagement of IT employees which will ultimately lead to the achievement of organizational goals. Important policies and procedures may include fair recruitment and selection, flexi-timing, aid in balancing work and life, and fair promotional policies.

In addition, banks can strive to improve IT employee engagement by adopting high-performance work practices (i.e. training, empowerment and rewards), providing clear managerial expectations and subsequent feedback, supervisor support (i.e. regular meetings, informal mentorship and training programs), and implementing IT employee recognition programs, along with profit-sharing opportunities, financial bonuses or even paid time off. 
As a result, it can be concluded that it is the role of leaders to connect IT employees emotionally with organizational roles and responsibilities as increased IT employee engagement results in increased organizational bottom lines.

Finally, adopting strategies that improve both engagement and satisfaction levels of IT employees will create benefits for both IT employees and employer as engaged and satisfied IT employees are those who have found jobs that meet their expectations and create personal fulfilment which makes them happy and committed employees. These IT employees, thus, see it fit to pay back their organizations by performing requested tasks and roles and achieving goals and objectives, which is likely to improve organizational performance.

\subsection{Limitations and Future Research}

The majority of studies, regardless of how well they are conducted, face some limitations. Nonetheless, these limitations are deemed useful as they provide guidance for future research. The first limitation that can be mentioned is that this study chose the IT Employees from IT departments in banking sector as the main area of emphasis to conduct the study on. Other studies wishing to study the same topic may choose other Employees from other departments or sectors to conduct the study on either service or manufacturing companies that would benefit from the results of the study.

Furthermore, this study employed quota sampling in order to have a representative sample from the IT departments in the banks followed by simple random sampling. However, using quota sampling reduces the generalizability of the results to the population, therefore simple random sampling was employed to improve the generalizability of the results. Future researchers are recommended, if possible, to use other sampling techniques such as stratified random sampling to improve the efficiency of the sampling design where all the groups are adequately sampled and comparisons among groups are possible.

Another limitation is the scales used to measure the various concepts of this study. Employee engagement was measured using a three factor model called the Utrecht Work Engagement Scale (UWES) comprised of vigor, absorption, and dedication (Schaufeli et al., 2009). Future researchers are advised to use other scales mentioned in the literature to measure employee engagement and see whether similar or comparable results would be obtained. This also goes for the scales used to measure job satisfaction and organizational performance. Moreover, this study emphasized job satisfaction as the mediator between IT employee engagement and organizational performance.

Other researches may choose to investigate whether a moderating role is more appropriate or whether other variables can be used to mediate the relationship other than job satisfaction. In addition, other variables can be used to help increase and understand the explained variance in organizational performance depending on the interests of the researchers and the recommendations of previous studies. Researchers are also encouraged to conduct a comparative study using the model developed in this study and previous models associated with organizational performance in an effort to reach the best model that suits the specifications of the particular organization, department, sector, or country in which the study was conducted.

Additionally, this paper investigated the effect of IT employee engagement on organizational performance through the mediating role of job satisfaction in the Jordanian context. However, the possibility to generalize the results to other countries with different characteristics needs to be verified by executing similar research projects which may add more value to the literature. It is thus encouraged that future researchers conduct an exhaustive examination of different countries to determine whether culture affects the results. Finally time limitations affected a number of decisions during its implementation. For example, more complex data analysis techniques such as hierarchical regression or Structural Equation Modelling (SEM) could have been utilized to test the mediation effect proposed in this study, thereby improving the strength and reliability of this study.

\section{Funding}

The author(s) received no financial support for the research, authorship, and/or publication of this article.

\section{Acknowledgments}

The authors are grateful to the senior editor, associate editor, and three anonymous reviewers for their invaluable guidance and insightful comments. as well as we thank all bank managers, head of the IT departments, all IT employees participated in this research for their collaboration.

\section{References}

Alarcon, G. M., \& Edwards, J. M. (2011). The Relationship of Engagement, Job Satisfaction and Turnover Intentions. Stress and Health, 27(3), 294-298.

Albdour, A. A., \& Altarawneh, I. I. (2014), Employee engagement and organizational commitment: Evidence from Jordan. International Journal of Business, 19(2), 178-192. 
Al-Fayoumi, N. A., \& Abuzayed, B. M. (2009). Assessment of the Jordanian Banking Sector within the Context of GATS Agreement. Banks and Bank Systems, 4(2), 69-79.

Amhalhal, A., Anchor, J., \& Dastgir, S. (2015). The Effectiveness of the Use of Multiple Performance Measures: The Influence of Organizational Contingencies. London: Sage.

Anitha J. (2014). Determinants of Employee Engagement and their Impact on Employee Performance. International Journal of Productivity and Performance Management, 63(3), 308-323.

Ariani, D. (2013). The Relationship between Employee Engagement, Organizational Citizenship Behavior, and Counterproductive Work Behavior. International Journal of Business Administration, 4(2), 46-56.

Association of Banks in Jordan (2016). Development of the Jordanian Banking Sector 2003-2012. Retrieved from http://www.abj.org.jo/enus/developmentofthejordanianbankingsector.aspx

Back, K. J., Lee, C. K., \& Abbott, J. (2011). Internal Relationship Marketing: Korean Casino Employees’ Job Satisfaction and Organizational Commitment. Cornell Hospitality Quarterly, 52(2), 111-124.

Bagnato, G., \& Paolino (2009). HRM Practices, Work Engagement and Firm Performance: An Empirical Study. Ticonzero, 95.

Bailey, A. A., Albassami, F., \& Al-Meshal, S. (2016), the roles of employee job satisfaction and organizational commitment in the internal marketing-employee bank identification relationship. International Journal of Bank Marketing, 34(6), 821-840.

Bakker, A., \& Schaufeli, W. (2008). Positive Organizational Behavior: Engaged Employees in Flourishing Organizations. Journal of Organizational Behavior, 29(2), 147-154.

Bandura, R., \& Lyons, P. (2014). Situations-Vacant Fall where Employees are Engaged Involvement Boosts Various Aspects of Organizational Performance. Human Resource Management International Digest, 22(5), 22-25.

Baron, R. M., \& Kenny, D. A. (1986). The Moderator-Mediator Variable Distinction in Social Psychological Research: Conceptual, Strategic, and Statistical Considerations. Journal of Personality and Social Psychology, 51, 1173-1182.

Bednarska, M., \& Szczyt, M. (2015). Variations in Job Satisfaction in Service Industries: Comparative International Analysis. Foresight, 17(6).

Brunetto, Y., \& Farr-Wharton, R. (2004). A Case Study Examining the Impact of Public Sector Nurses Perception of Workplace Autonomy on their Job Satisfaction: Lessons for Management. International Journal of Management and Organisational Behaviour, 8(5), 521-539.

Bryman, A., \& Bell, E. (2015). Business Research Methods (4th Ed), Oxford Press.

Caplan, J. (2013). Strategic Talent Development: Develop and Engage all your People for Business Success. London: Kogan Page.

Chadha, P. (2007). The Orderly Workplace: An Exploration into Holistically Disciplined Work Life. India: Macmillan Publishers.

Chen, Y. (2007). Relationships among Service Orientation, Job Satisfaction, and Organizational Commitment in the International Tourist Hotel Industry. Journal of American Academy of Business, 11(2), 71-82.

Clark, A. (2001). What Really Matters in a Job? Hedonic Measurement using Quit Data. Labour Economics, 8 , 223-242.

Daily, C., \& Near, J. (2000). CEO Satisfaction and Firm Performance in Family Firms: Divergence between Theory and Practice. Social Indicators Research, 51, 125-170.

Daniel, I., \& Prajogo, B. C. (2017). The individual and organizational level effects of TQM practices on job satisfaction. International Journal of Manpower, 38(2), 215-225. https://doi.org/10.1108/IJM-12-2014-0240

Di Paolo, A. (2016). Endogenous: Occupational Choices and Job Satisfaction among Recent Spanish PhD Recipients. International Journal of Manpower, 37(3), 511-535.

Efraty, D., \& Sirgy, M. (1990). The Effects of Quality of Working Life (QWL) on Employee Behavioral Responses. Social Indicators Research, 22(1), 31-47.

Ellinger, A., Ellinger, A., Yang, B., \& Howton, S. (2002). The Relationship between the Learning Organization Concept and Firm's Financial Performance: An Empirical Assessment. Human Resource Development 
Quarterly, 13, 5-22.

Estes, B., \& Wang, J. (2008). Workplace Incivility: Impacts on Individual and Organizational Performance. Human Resource Development Review, 7, 218-240.

Faragher, E., Cass, M., \& Cooper, L. (2005). The Relationship between Job Satisfaction and Health: A MetaAnalysis. Journal of Occupational and Environmental Medicine, 62, 105-112.

Ferreira, P., \& de Oliveira, E. (2014). Does Corporate Social Responsibility Impact on Employee Engagement? Journal of Workplace Learning, 26(3/4), 232-247.

Firth, L., Mellor, D., Moore, K., \& Loquet, C. (2004). How Can Managers Reduce Employee Intention to Quit? Journal of Managerial Psychology, 19(2), 170-187.

Fisher, C. (2000). Mood and Emotions while Working: Missing Pieces of Job Satisfaction? Journal of Organizational Behavior, 21, 185-202.

Forgas, G., \& George, J. (2001). Affective Influences on Judgment and Behavior in Organization: An Information Processing Perspective. Organizational Behavior and Human Decision Processes, 86(1), 3-34.

Fraser, J. A. (2001). White-Collar Sweatshop: The Deterioration of Work and its Rewards in Corporate America. New York: Norton and Company.

Gorgievski, M., Bakker, A., \& Schaufeli, W. (2010). Work Engagement and Workaholism: Comparing the SelfEmployed and Salaried Employees. Journal of Positive Psychology, 5(1), 83-96.

Goslin, P. (2005). Managing Employee Satisfaction of Volunteers in South African Sport. African Journal for Physical Health Education, 12(1), 30-40.

Hair, J. F., Black, W. C., Babin, B. J., Anderson, R. E, \& Tatham, R. L. (2010). Multivariate Data Analysis, 7th edition, New York: Macmillion Publishing Company.

Halbesleben, J. (2010). A Meta-Analysis of Work Engagement: Relationships with Burnout, Demands, Resources, and Consequences. In A. B. Bakker \& M. P. Leiter (Eds.), Work Engagement: A Handbook of Essential Theory and Research (pp. 102-117). Hove, East Sussex: Psychology Press.

Halbesleben, J., \& Wheeler, A. (2008). The Relative Roles of Engagement and Embeddedness in Predicting Job Performance and Intention to Leave. Work \& Stress, 22, 242-256.

Harter, J., Schmidt, F., \& Keyes, C. (2002). Well-being in the Workplace and its Relationship to Business Outcomes: A Review of the Gallup Studies in Keyes, C.L. and Haidt, J. (Eds), Flourishing: The Positive Person and the Good Life, American Psychological Association, Washington, DC.

Hassanain, M. (2006). Factors Affecting the Development of Flexible Workplace Facilities. Journal of Corporate Real Estate, 8, 213-220.

Hernaus, T., Bach, M., \& Vuksic, V. (2012). Influence of Strategic Approach to BPM on Financial and NonFinancial Performance. Baltic Journal of Management, 7(4), 376-396.

Hwang, I., \& Chi, D. (2005). Relationships among Internal Marketing, Employee Job Satisfaction and International Hotel Performance: An Empirical Study. International Journal of Management, 22(2), 285-294.

Judge, T., \& Ilies, R. (2004). Affect and Job Satisfaction: A Study of their Relationship at Work and at Home. Journal of Applied Psychology, 89(4), 661-673.

Judge, T., Piccolo, R., Podsakoff, N., Shaw, J., \& Rich, B. (2010). The Relationship between Pay and Job Satisfaction: A Meta-Analysis of the Literature. Journal of Vocational Behavior, 77(2), 157-167.

Kanyurhi, E., \& Akonkwa, D. (2016), Internal Marketing, Employee Job Satisfaction, and Perceived Organizational Performance in Microfinance Institutions. International Journal of Bank Marketing, 34(5), 773-796.

Karatepe, O. (2011). Procedural Justice, Work Engagement, and Job Outcomes: Evidence from Nigeria. Journal of Hospitality Marketing and Management, 20(8), 855-878.

Karatepe, O., \& Demir, E. (2013). Linking Core Self-Evaluations and Work Engagement to Work-Family Facilitation: A Study in the Hotel Industry. International Journal of Contemporary Hospitality Management, 26(2), 307-323.

Karatepe, O., \& Olugbade, O. (2009). The Effects of Job and Personal Resources on Hotel Employees' Work Engagement. International Journal of Hospitality Management, 28(4), 504-512. 
Koonmee, K., Singhapakdi, A., Virakul, B., \& Lee, D. (2010). Ethics Institutionalization, Quality of Work Life, and Employee Job-Related Outcomes: A Survey of Human Resource Managers in Thailand. Journal of Business Research, 63(1), 20-26.

Koys, D. (2003). How the Achievement of Human-Resources Goals Drives Restaurant Performance. Cornell Hotel and Restaurant Administration Quarterly, 44(1), 17-24.

Langfred, C., \& Moye, N. (2004). Effects of Task Autonomy on Performance: An Extended Model Considering Motivational, Informational, and Structural Mechanisms. Journal of Applied Psychology, 89(6), 934-945.

Latif, M., Ahmad, M., Qasim, M., Mushtaq, M., Ferdoos, A., \& Naeem, H. (2013). Impact of Employee's Job Satisfaction on Organizational Performance. European Journal of Business and Management, 5(5), 166-171.

Lee, Y. K., Nam, J. H., Park, D. H., \& Lee, K. A. (2006). What Factors Influence Customer-Oriented Prosocial Behavior of Customer-Contact Employees? Journal of Services Marketing, 20(4), 251-264.

Lucky, E., Minai, M., \& Abdul Rahman, H. (2013). Impact of Job Security on the Organizational Performance in Multi-ethnic Environments. Research Journal of Business Management, 7(1), 64-70.

MacKinnon, D., Fairchild, A., \& Fritz, M. (2007). Mediation Analysis. Annual Review of Psychology, 58, 593-614.

Marciano, P. (2010), Carrots and Sticks Don't Work: Build a Culture of Employee Engagement with the Principles of Respect. New York: McGraw Hill Professional.

Mohr, A., \& Puck, J. (2007). Role Conflict, General Manager Job Satisfaction and Stress and the Performance of International Joint Ventures. European Management Journal, 25, 25-35.

Mone, E., \& London, M. (2010). Employee Engagement through Effective Performance Management: A Practical Guide for Managers. Routledge, New York, NY.

Mount, M., Ilies, R., \& Johnson, E. (2006). Relationship of Personality Traits and Counterproductive Work Behaviors: The Mediating Effects of Job Satisfaction. Personnel Psychology, 59(3), 591-622.

Musgrove, C. F., Ellinger, A. E. \& Ellinger, A. D. (2014), Examining the influence of strategic profit emphases on employee engagement and service climate. Journal of Workplace Learning, 26(3/4), $152-171$.

Myers, R. (1990). Classical and Modern Regression with Applications. Duxbury Press, Boston, MA.

Obeidat, B., El-Rimawi, S., Maqableh, M., \& Al-Jarrah, I. (2013). Evaluating the Profitability of the Islamic Banks in Jordan. European Journal of Economics, Finance and Administrative Sciences, 56 (January), 27-36.

Radosevich, D., Radosevich, D., Riddle, M., \& Hughes, P. (2008). Goal Orientation as a Predictor of Cognitive Engagement, Performance, and Satisfaction. Journal of the Academy of Business \& Economics, 8(3), 46-55.

Ramadan, B., Dahiyat, S., Bontis, N., \& Al-dalahmeh, M. (2017). Intellectual Capital, Knowledge Management and Social Capital within the ICT Sector in Jordan. Journal of Intellectual Capital, Vol.18. No. 2.

Rayton, B., \& Yalabik, Z. (2014). Work Engagement, Psychological Contract Breach and Job Satisfaction. The International Journal of Human Resource Management, 25(17), 2382-2400.

Saks, A. (2006). Antecedents and Consequences of Employee Engagement. Journal of Managerial Psychology, 21(7), 600-619.

Salanova, M., Agut, S., \& Peiro, J. (2005). Linking Organizational Resources and Work Engagement to Employee Performance and Customer Loyalty: The Mediation of Service Climate. Journal of Applied Psychology, 90(6), 1217-1227.

Sambamurthy, V., Bharadwaj, A., \& Grover, V. (2003). Shaping agility through digital options: Reconceptualizing the role of information technology in contemporary firms. MIS Quart., 27(2), 237-263.

Schaufeli, W., \& Bakker, A. (2004). Job Demands, Job Resources, and their Relationship with Burnout and Engagement: A Multi-Sample Study. Journal of Organizational Behavior, 25(3), 293-315.

Schaufeli, W., Bakker, A., \& Van Rhenen, W. (2009). How Changes in Job Demands and Resources Predict Burnout, Work Engagement, and Sickness Absenteeism. Journal of Organizational Behavior, 30(7), 893-917.

Schaufeli, W., Schaufeli, A., \& Salanova, M. (2006). The Measurement of Work Engagement with a Short Questionnaire. Educational and Psychological Measurement, 66(4), 701-716.

Sekaran, U., \& Bougie, R. (2013). Research Methods for Business (6th ed). United Kingdom: John Wiley \& Sons Ltd. 
Sempane, M., Rieger, H., \& Roodt, G. (2002). Job Satisfaction in Relation to Organisational Culture. Journal of Industrial Psychology, 28(2), 23-30.

Shahin, A. Naftchali, J., \& Pool, J. (2014). Developing a Model for the Influence of Perceived Organizational Climate on Organizational Citizenship Behaviour and Organizational Performance based on Balanced Score Card. International Journal of Productivity and Performance Management, 63(3), 290-307.

Shekari, H. (2015). Evaluating the Three Dimensions of Work Engagement in Social Security Organization of Yazd Province in Iran. Journal of Educational and Management Studies, 5(3), 168-174.

Shields, M. (2006). Unhappy on the Job. Health Report, 17(4), 82.

Shmailan, A. (2016). The Relationship between Job Satisfaction, Job Performance and Employee Engagement: An Explorative Study. Issues in Business Management and Economics, 4(1), 1-8.

SHRM, (2016). Employee Job Satisfaction and Engagement Report: Revitalizing a Changing Workplace. Retrieved from: https://www.shrm.org/hr-today/trends-and-forecasting/research-andurveys/documents/2016-employee-job-satisfaction-and-engagement-report.pdf

Sobel, M. (1982). Asymptotic Confidence Intervals for Indirect Effects in Structural Equation Models. In S. Leinhart (Ed.), Sociological Methodology. San Francisco: Jossey-Bass.

Song, J., Kolb, J., Lee, U., \& Kim, H. (2012). Role of Transformational Leadership in Effective Organizational Knowledge Creation Practices: Mediating Effects of Employees' Work Engagement. Human Resources Development Quarterly, 23(1), 65-101.

SQW Consulting, (2010). Best Strategies in Skills Utilisation. Retrieved, from $\mathrm{http} / / / \mathrm{www}$. scottishenterprise.com/ /media/SE/Resources/Documents/ABC/Best-strategies-In-skillsutilisation-summary.ashx

Stringer, L. (2006). The Link between The Quality of The Supervisor-Employee Relationship and The Level of The Employee's Job Satisfaction. Public Organization Review, 6, 125-142.

Surujlal, J., \& Singh, P. (2003). Human Resources Management of Professional Sport Coaches in South Africa. African Journal for Physical, Health Education, Recreation and Dance, 50-58.

Thompson, B., \& Daniel, L. (1996). Factor Analytic Evidence for the Construct Validity of Scores: A Historical Overview and Some Guidelines. Educational and Psychological Measurement, 56(2).

Tuna, M., Ghazzawi, I., Yesiltas, M., Tuna, A. A., \& Arslan, S. (2016). The effects of the perceived external prestige of the organization on employee deviant workplace behavior. International Journal of Contemporary Hospitality Management, 28(2), 366-396.

UPA (2015). Testing Mediation with Regression Analysis. Retrieved from: http://www.upa.pdx.edu/IOA/newsom/da2/ho_mediation.pdf

Wefald, A., \& Downey, R. (2009). Construct Dimensionality of Engagement and its Relation with Satisfaction. Journal of Psychology, 143(1), 91-112.

Weiss, H., \& Cropanzano, R. (1996). Affective Events Theory: A Theoretical Discussion of the Structure, Causes and Consequences of Affective Experiences at Work. In L. L. Cummings \& B. M. Staw (Eds), Research in Organizational Behavior, 18, 1-74, Greenwich, CT: JAI Press.

Weiss, H., Nicholas, J., \& Daus, C. (1999). An Examination of the Joint Effects of Affective Experience and Job Beliefs on Job Satisfaction and Variations in Affective Experiences over Time. Organizational Behavior and Human Decision Processes, 78(1), 1-24.

Yalabik, Z. Y., Bruce, A. R., \& Andriana, R. (2017). Facets of job satisfaction and work engagement. Evidencebased HRM: A Global Forum for Empirical Scholarship, 5(3), 248-265, https://doi.org/10.1108/EBHRM-082015-0036

Yee, R., Yeung, A., \& Cheng, T. (2008). The Impact of Employee Satisfaction on Quality and Profitability in HighContact Service Industries. Journal of Operations Management, 26(5), 651-668.

Yee, R., Yeung, A., \& Cheng, T. (2011). The Service-Profit Chain: An Empirical Analysis in High-Contact Service Industries. International Journal of Production Economics, 130(2), 236-245.

Yoon, M., \& Suh, J. (2003). Organizational Citizenship Behaviors and Service Quality as External Effectiveness of Contact Employees. Journal of Business Research, 56(8), 597-611. 
Zikmund, W., Babin, B., Carr, J., \& Griffin, M. (2013). Business Research Methods. CENGAGE Learning Custom Publishing.

\section{Copyrights}

Copyright for this article is retained by the author(s), with first publication rights granted to the journal.

This is an open-access article distributed under the terms and conditions of the Creative Commons Attribution license (http://creativecommons.org/licenses/by/4.0/). 